University of Rhode Island

DigitalCommons@URI

Open Access Master's Theses

1978

\title{
The Effects of Sevin (1-Naphthyl N-Methylcarbamate) on Morphology and Root Anatomy of Glycine max (L.) Merrill
}

Laurence M. Raine

University of Rhode Island

Follow this and additional works at: https://digitalcommons.uri.edu/theses

\section{Recommended Citation}

Raine, Laurence M., "The Effects of Sevin (1-Naphthyl N-Methylcarbamate) on Morphology and Root Anatomy of Glycine max (L.) Merrill" (1978). Open Access Master's Theses. Paper 973.

https://digitalcommons.uri.edu/theses/973

This Thesis is brought to you for free and open access by DigitalCommons@URI. It has been accepted for inclusion in Open Access Master's Theses by an authorized administrator of DigitalCommons@URI. For more information, please contact digitalcommons-group@uri.edu. 


\section{THE EFFECTS OF SEVIN (1-NAPHTHYL \\ N-METHYLCARBAMATE) (N MORPHOLOGY AND ROOT \\ ANATOMY OF GLYCINE MAX (L.) MERRILL \\ BY \\ LAURENCE M. RAINE}

A THESIS SUBMITTED IN PARTIAL FULFILIMENT OF THE REQUIREMENTS FOR THE DEGREE OF

MASTER OF SCIENCE

IN

BOTANY

UNIVERSITY OF RHODE ISLAND

1978 
MASTER OF SCIENCE THESIS

OF

\section{LAURENCE M. RAINE}

Approved:

Thesis comittee

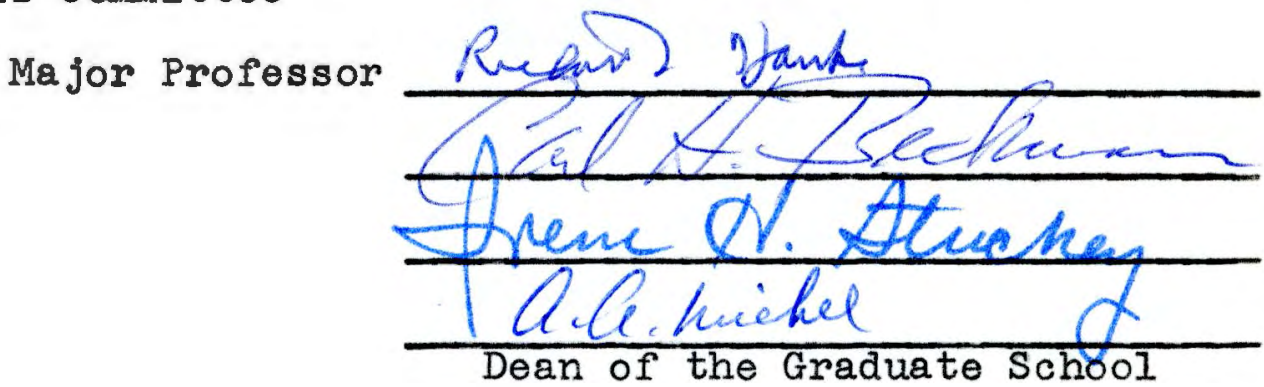

UNIVERSITY OF RHODE ISLAND 
"The roadsides, once so attractive, were now Iined with browned and withered vegetation as though swept by fire"

Rachel Carson 1962 


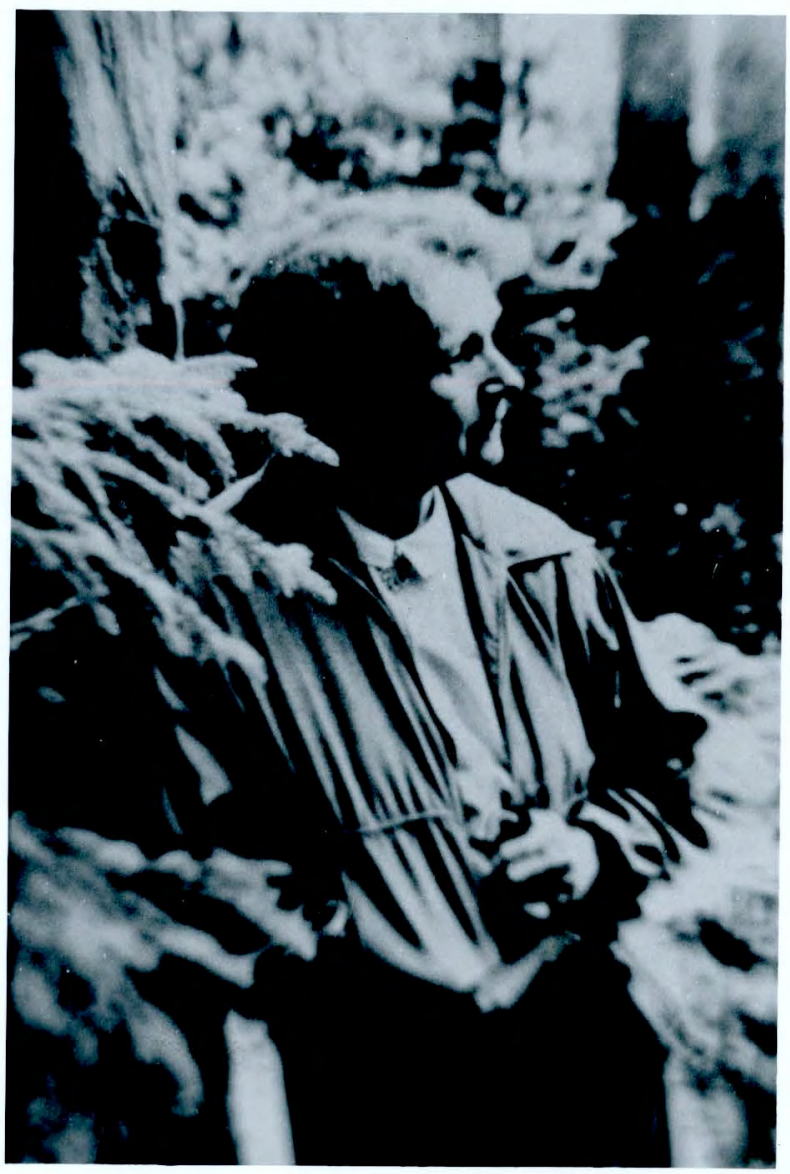


ABSTRACT

This study investigated the effects Sevin (1-naphthyl $\mathrm{N}$-methylcarbamate) had on the morphology and root anatomy of soybeans (Glycine max (L) Merr.).

Morphological observations revealed that as the concentration of Sevin increased, the cotyledons, hypocotyl and epicotyl decreased in size. Absence of a pigment (presumably anthocyanin) normally present in the petioles and hypocotyl, was noticed at all applications of Sevin. Bmergence of primary and trifoliate leaves was delayed as the concentration of Sevin increased. Increased Sevin concentrations produced thin, white roots with numerous laterals. With increased concentrations, purple pigment appeared on both taproots and lateral roots.

Growth rates of roots, when analyzed by Duncan's Modified Multiple Range Test, were not significant between 2, 9 and $19 \mathrm{ppm}$ of Sevin, but were significant at the 1\% level for 21,25 and $55 \mathrm{ppm}$ of Sevin.

Roots of treated soybeans exhibited development of lateral root primordia close to the root apex. This suggests that the cells failed to elongate in advance of differentiation. There appeared to be no change in the quiescent center for all Sevin concentrations. Noticeable vacuolization of cortical, stelar, epidermal and root cap cells occurred at 21,25 and $55 \mathrm{ppm}$ of Sevin. At increased Sevin concentrations, the root cap was usually sloughed off or was lacking. 
An autoradiographic study indicated that the translocation of $14 \mathrm{C}$-Sevin was predaminately apoplastic with possible accumulation of $14 \mathrm{C}$-Sevin into the symplast.

Morphological and anatomical analyses revealed few or no appreciable differences at 2, 9 and $19 \mathrm{ppm}$ of Sevin, but at 21,25 and $55 \mathrm{ppm}$, noticeable change in root structure did occur.

Sevin has low mammalian toxicity, short half life and at low threshold concentrations does not produce visible anatomical or growth changes. These properties make Sevin one of the most useful insecticides avaliable today. 


\section{ACKNOWLEDGEMENTS}

As the late Jenny Grosinger so wisely said, "To me there are no strangers, only friends I have not met before."

Thank you, Dr. Hauke, for your advice in the research and preparation of this manuscript. Thank you, Dr. Beckman, for your counsel in the preparation of this thesis. A most special thank you to $\mathrm{Dr}$. C. Rice, who served on my thesis committee but could not be at the defense. I thank Dr. Hull for his invaluable assistance in the preparation and interpretation of the radioassay studies. Dr. Stuckey, thank you so much for joining the thesis cormittee at the last moment. What an honor it is that you served on both Abigail's and my thesis comittees.

My last acknowledgement is to Abigail Kelley Rainethank you for "nudging" me to write, to think and most of all to be happyl 
ABSTRACT...............................

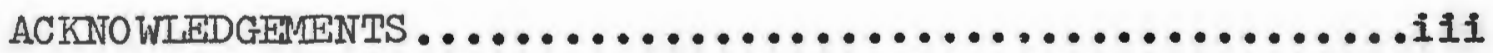

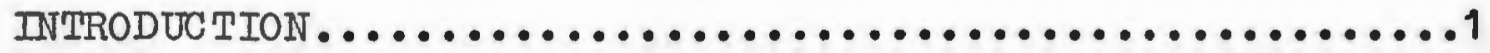

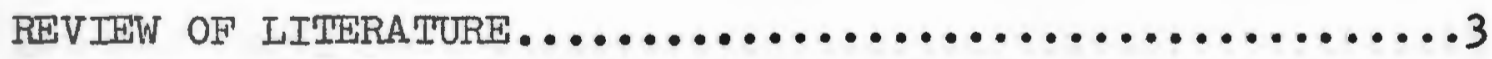
The effects of insecticides on root anatany.......... Anatamy of Glycine max (I.) Merrill.............. Metabolism and persistense of Sevin in plants

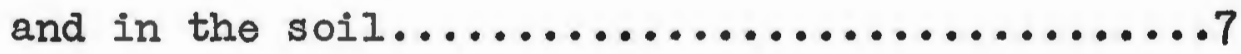

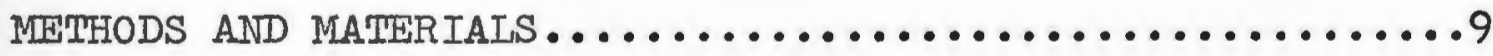

Plant material and plant growth...............

Microtechnique..........................10

Colorimetric determination of insecticide

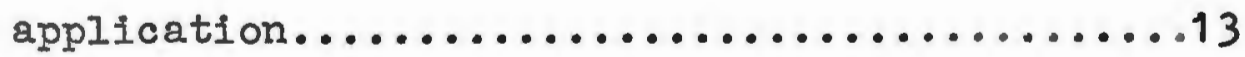

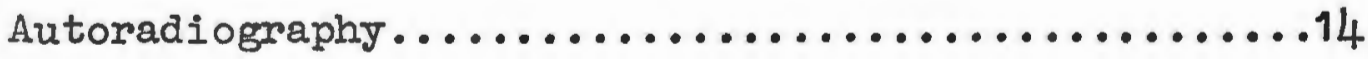

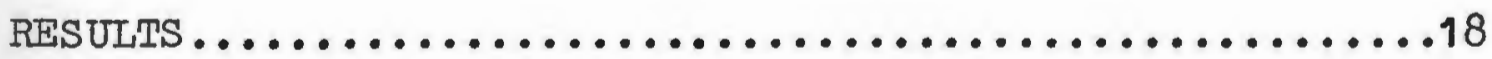

Morphological observations.................18 Effects on cotyledons..................18 Effects on hypocotyl and epicotyl..........18 Effects on primary and trifoliate leaf

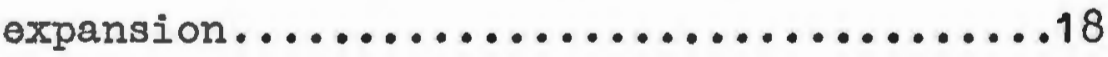

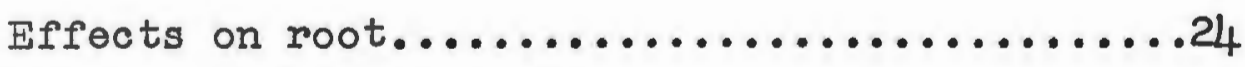

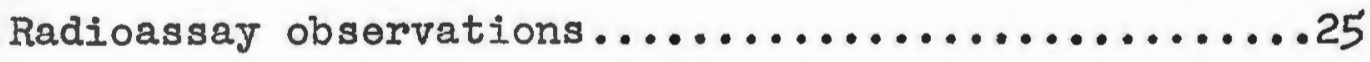

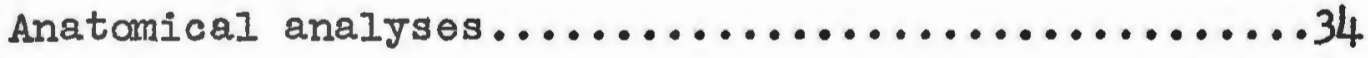

The effects of Sevin on the quiescent center...41

The effects of Sevin on the root cap and

epidermis.......................41 
The effects of Sevin on the cortex...........41 The effects of Sevin on the vascular cylinder..42

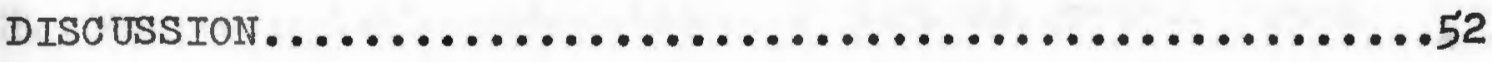

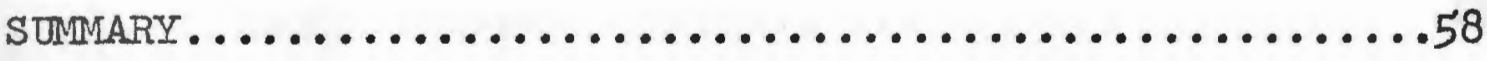

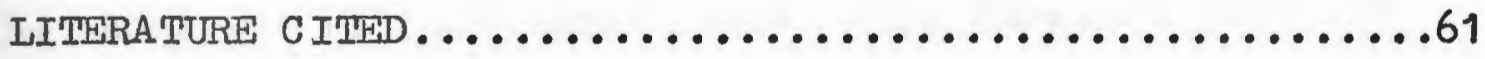

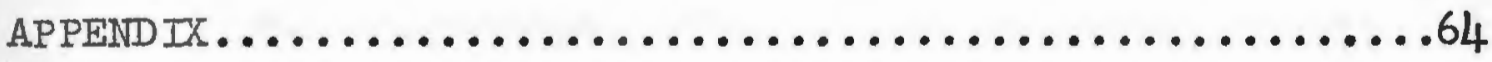




\section{IIST OF TABIES}

1. Modified Shive's Nutrient Solution................11

2. Morphological observations of soybean growth versus

Sevin concentration.....................19

3. Analysis of root growth data using Duncan's Modified

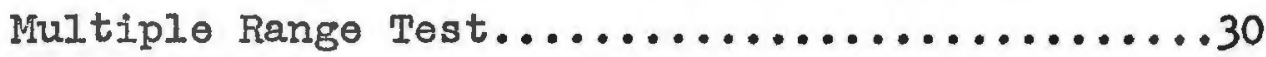

4. Specific Activity, Total Activity and Percent

14

Distribution of $C$-Sevin in sojbean roots,

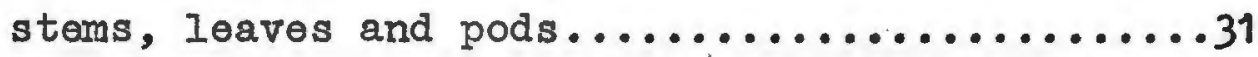




\section{LIST OF FIGURES}

1. Experimental design for the treatment of soybeans 14 with C-Sevin.

2. A) Soybean plants treated with 0,9 and 19 ppm Sevin..20

B) Soybean plants treated with 0,25 and 55 ppm

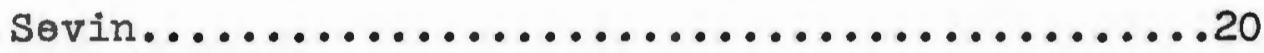

3. Soybean plants treated with 0,21 and 2 ppm Sevin.....22

4. Root tip growth at various concentrations of Sevin....26

5. Lateral root emergence at various concentrations of

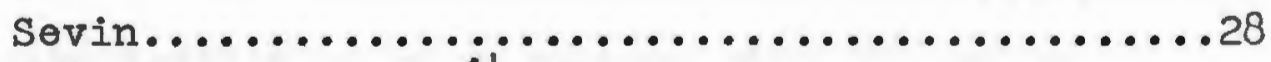
14

6. Percent distribution of C-Sevin to various plant

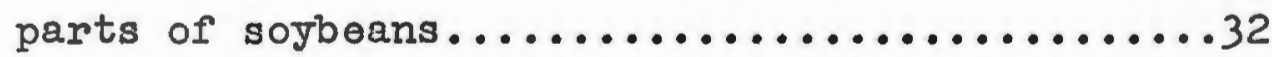

7. A) Autoradiograph following an application of 4.8
$M C i$ of ${ }^{4}$-Sevin to the nutrient solution.......35 14

B) Autoradiograph enlargement of trifoliate leaf.....35

8. A) Application site of $1.6 \mathrm{MC}$ i of ${ }^{14} \mathrm{C}$-Sevin to the

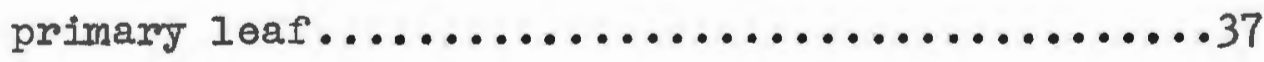

B) Autoradiograph following the application of 14

$1.6 \mathrm{MC}$ i of C-Sevin to the primary leaf.......37 14

9. A) Application site of $1.6 \mu \mathrm{Ci}$ of $\mathrm{C}$-Sevin to the

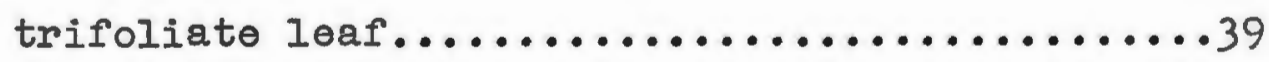

B) Autoradiograph following the application of $1.6 \mathrm{kCi}$

of ${ }^{14} \mathrm{C}$-Sevin to the trifoliate leaf............39

10. A) Longitudinal section of control root............44

B) Cross section of control root................4 
11. A) Longitudinal section of root treated with 21

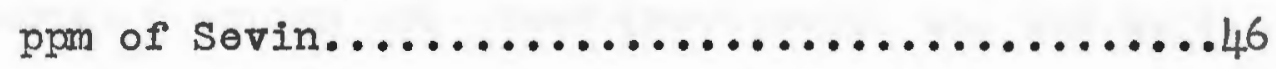

B) Longitudinal section of root treated with 21

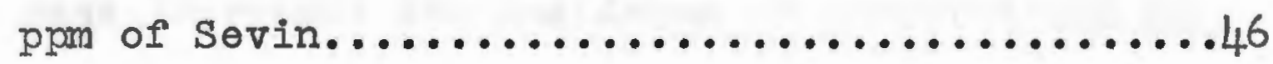

12. A) Longitudinal section of root treated with 25

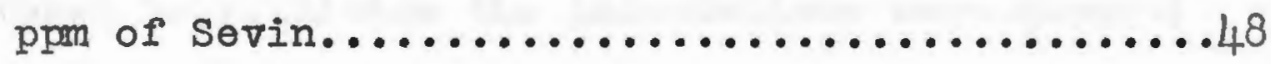

B) Maturing tracheary element................... 8

13. A) Longitudinal section of root treated with 55

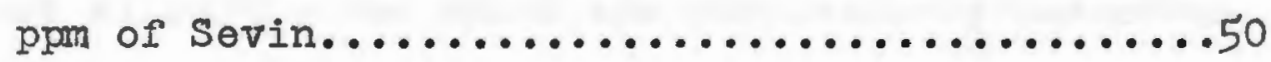

B) Cross section of root treated with 55 pom of

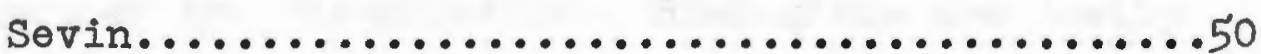




\section{INTRODUCTION}

Agricultural technology has increased crop production through proper planning and plant propagation and has as a result brought about a "green revolution". Some of these practices have increased the incidence of infestations by insects and fungi, and many of the chemical compounds that were developed to eliminate the infestations were harmful to the biosphere.

Within the last few decades, increasing dependence upon the use of pesticides which are particularly hazardous to animal and human life, has led to laws that regulate their production and distribution. Biologists are justly concerned with the effects of pesticides on animals and their long term effects on future generations, but there is less concern when an insecticide is applied to a crop, unless it is highly phytotoxic.

Research has been conducted on translocation, absorption, metabolism and retention of insecticides in plants, but few studies have addressed the problem of the effects of insecticides on the anatomy of the plants. There is no question that the heavy use of insecticides has resulted in serious residue problems in many agricultural areas, so it is highly desirable to determine what levels of residues affect plant growth, and how this effect is expressed anatomically.

Sevin is the most widely used carbamate insecticide in the United States today (von Rumker et al., 1974). It is 
a broad spectrum insecticide that controls many economically important insects, some of which are the Painted Lady Butterfly larvae (Vanessa cardui), Green Cloverworm (Plathypena scalira) and Mexican Bean Beetle (Epilachna varivestis). It is unique in having a low mamalian toxicity $(560 \mathrm{mg} / \mathrm{kg}$ in rats) as well as low persistance in the enviroment (8135 days, depending on the substrate) (Caro et al., 1974). Soybeans are the most important cash crop in the United States and are an important food product for human and livestock consumption (Howell, 1975). A review of the literature has revealed no specific studies on the effects of Sevin on soybeans (while applications of Sevin at 2 lbs/ acre of active ingredient have been observed to be phytotoxic under field conditions). Therefore, this thesis is concerned with the morphological and anatomical effects of various concentrations of Sevin on the soybean. 


\section{LITERATURE REVIEW}

The effects of insecticides on root anatomy.

The pertinent literature on the effects of insecticides on plant anatomy is concerned with the $\gamma$ isomer of hexachlorocyclohexane, commonly known by the trade name Lindane. Kostoff (1948), Scholes (1953), Simkover and Shenefelt (1952), Nybor and Knutsson (1947) and Ball (1956) noted that root apices of plants treated with these compounds were club-shaped, resembling the effects produced by colchicine. Increased numbers of multinucleate cells in the root apex. were observed in the roots of monocotyledons, dicotyledons and gymnosperms.

Lichtenstein et al. (1962) reported that when corn and peas were subjected to $30 \mathrm{ppm}$ Sevin, the roots were shorter and thicker than the control roots, and for most species, there was an overall reduction in plant size. Lateral roots formed within $0.5 \mathrm{~cm}$ of the root apex and were shorter than those in the plants grown in untreated sand. A dark purplish color appeared on the lower portions of the roots. The primary metabolite of Sevin, 1-naphthol, produced no effects on the length of corn and pea roots, although they did exhibit the purple color on its lower surfaces.

Lichtenstein categorized the anatomical changes as a "growth inhibition". The observation of differentiated protoxylem, metexylem, protophloem and endodermis close to the root apex, suggested that development of cells close to the root apex was "precocious". Sevin induced growth in- 
hibition with noticeable tracheary elements differentiated $\operatorname{clos} \theta$ to the root apex in a unique wedge-shaped pattern opposite the proxylem poles.

Lichtenstein also observed prolific development of lateral roots in both peas and corn treated with Sevin. Anatomical changes in corn were differentiation of tracheary elements close to the root apex and significant cell wall change illustrated by retention of safranin stain in a peripheral band of cells in the vascular cylinder that included the endodermel tissues.

The chlorinated hydrocarbons, dieldrin and chlordane, produced the same results as noted for Sevin. Chlordane caused hypertrophy of the xylem and phloem parenchyma and a slight modification of the root apex. Lindane, also a chlorinated hydrocarbon, produced hypertrophic and hyperplastic effects on corn and pea roots. Irregular enlargement of cells in the vascular cylinder and cortex caused a brodening of the root. Stimulation of cell division in the pericycle and vascular cylinder caused distortion in the appearance of the root when sectioned. Lichtenstein also noted that Iindane produced multiple nuclei in the root apices of pea and corn roots. Charnetski (1973), working with Lindane on pea roots, noted Lichtenstein's observations and concluded that the mulitnucleated cells were the product of microtublar inhibition which produced incomplete cell divisions with partial cell walls projectIng into the lumen of each cell. The lateral roots were 
also noticeably clubbed in appearance.

Anatomy of Glycine max (L) Merr.

The anatomy of soybeans has been studied by Miksche (1961), Weaver (1960), and Mitchell and Russell (1971). It is an upright plant, and depending on the variety, has a root system consisting of a taproot and extensive lateral roots. The stem is pigmented (presumably anthocyanin), pubescent and the cotyledons exhibit netted venation. The primary leaves are simple and opposite and the subsequent leaves are trifoliate and alternate. Inconspicuous flowers arise at the second internode and normally produce a pod containing two to four seeds.

The apical meristem of the shoot is structured into four zones: 1) the central mother cell zone, 2) two layers of surface initials, 3) peripheral and 4) rib meristem zones (Sun, 1957). Prior to germination, the epicotyl of the embryo possesses several foliage leaves and primordium of the first trifoliate leaf prior to dormancy (Miksche, 1961).

After 32 hours of imbibition, the soybean seed radicle has initiated mitotic figures. The mitotic divisions are noted 400-800 $\mathrm{mm}$ above the apical generating zone in the cortex region. Mitotic figures are noted in the stelar regions approximately 36 to 48 hours after germination. The apical generation zone exhibits mitotic figures after 
48 hours of germination. The root meristem is composed of several stratified layers which are oriented at right angles to the root axis and are designated as the cammon initial region (Miksche, 1961).

The distal cells of the quiescent center produce the central cells of the root cap by periclinal divisions. The peripheral portion of the root cap is produced by periclinal and oblique divisions of the peripheral lateral derivations of the quiescent center. The stelar initials form a hemispherical body of cells at the proximal portion of the quiescent center. The vascular pattern of soybeans reveals distally a tetrarch and exarch radial arrangement. According to weaver (1960), the primary xylem of the roothypocotyl-cotyledon axis is a single unit. Bifurcation of the four xylem strands into eight strands produces an endarch xylem in the upper hypocotyl where previously the strands were tangentially oriented in the root.

Sun (1955, 1957) reported that the lateral roots developed from the perfeycle at the loci directly opposite the four protoxylem poles. Mitchell and Russell (1971) reported that under field conditions, lateral roots developed 3-7 days after the taproot. Growth and development of lateral roots responded to various phases of plant growth i.e., young vegetative cover, seed formation, and seed set. The lateral roots eventually overtake the primary taproot in length and then grow horizontally until seod set when a strong positive geotropism develops in the lateral roots 
and from then on the main root system is composed of lateral roots.

The analysis of soybean root anatomy is a basis for understanding the effects of Sevin on the root anatomy, the subject of this thesis.

Metabolism and Persistance of Sevin in Plants and in the SoII

Sevin (1-naphthyl $N$-methylcarbamate) is a naphthylene ring with a carbamate group attached to the first carbon atom.

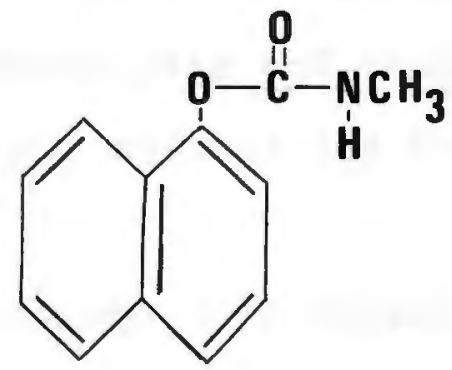

Trade names are Sevin, Turcarnan, Ravyon, Karbaspray and Hexarin. Sevin is an alkyl carbamate insecticide which is soluble in water at $40 \mathrm{ppm}$ at $30^{\circ} \mathrm{C}$ and is moderately toxic. Half-life persistence in the soil depends on both enviromental and soil factors.

Persistence of Sevin in soil is still being tested. Guseinov (1970), Ivanova and Molozhanova (1973) noted that even foliar applications of Sevin resulted in soil residues. Johnson and Stansbury (1963) determined that under field conditions Sevin in sandy loam has a half-life of eight days (equivalent to 35 days for $95 \%$ disappearance) with complete breakdown occurring within 40 days. Hazano et al. 
(1972) noted that the types of solls in rice paddies influenced the persistence of Sevin i.e., it was most persistent in clay loams and least persistent in sandy loams.

Caro et al. (1974) observed that under field condit:ions 135 days were necessary for $95 \%$ of the pesticide to decompose. This depended upon the method of Sevin application and the depth of the soil sampled since Sevin does move in the soil.

Degradation of Sevin to its primary metabolite, 1-naphthol, can occur as a result of ultraviolet irradiation and microbial action. Hydrolysis and oxidation of the parent compound to seven known metabolites have been demonstrated by Kuhr (1970).

Primary insect damage to soybeans are by leaf feeders. Soybeans an tolerate considerable defoliation without loss in seed yield after pods have been set. The Mexican Bean Beetle (Epilachna varivestis), Green Stink Bug (Acrosternum hilare) and Bean Leaf Beetle (Cerotama trifurcata)are considered as primary pests of soybeans (Nat. Acad. of Science, 1975). Often more than one species of foliar feeders can be present on soybeans.

Therefore, Sevin controls a number of economically important insects that attack soybeans and when properly applied is a fairly safe and effective carbamate insecticide (von Rumker et al., 1974). 


\section{METHODS AND MATERIALS}

Plant Material and Plant Growth

Soybean seed (Glycine max (L) Merr. 'Lee 68') was obtained from the Lone Pine Rice and Bean Farm, Carlisle, Arkansas. It was stored in plastic containers in a refrigerator. Preparations for seed germination consisted of 1) rinsing the seeds in distilled water, 2) soaking in the fungicide Arasan (2 tbl/gal) for 5 minutes and 3) air drying the seeds. The seeds were placed in plastic germinators $(32 \times 23 \times 7 \mathrm{~cm})$ which were lined with sterile paper toweling barely moistened with distilled water. A sheet of polyethylene under the germinator cover maintained the humidity within the germinator. The germinators were then placed in a Sherer growth chamber model CEL 25-7HL. Illumination within the chamber consisted of 12 incandescent and 10 flourescent bulbs yielding a light intensity of 13,500 to 15,500 lux. The photoperiod was maintained at a 12-hour day-12-hour night cycle. Temperature within the growth chamber was set at $28 \pm 0.5^{\circ} \mathrm{C}$ by day and $20 \pm 0.5^{\circ} \mathrm{C}$ by night.

Soybean seedlings, 4-days post germination, were selected with radicles over $1.0 \mathrm{~cm}$ in length. The radicles were marked $1.0 \mathrm{~cm}$ from the root apex with India Ink using a feather marker. Growth was recorded in 3 ways: 1) root tip growth in relation to an ink mark $1.0 \mathrm{~cm}$ from the root apex, 2) length from the root apex to the cotyledons and 3) distance of lateral roots from the root apex. Ottawa sand obtained fram the Ottawa Silica Co., Mystic, 
Connecticut, was used as a substrate for the experiments. To insure proper wetting of the sand, $100 \mathrm{ml}$ of distilled water was added to the dry sand. The dosage of Sevin (obtained from. Union Carbide Corporation, New Jersey-100\% Assay Technical Grade) used was determined in parts per million using moist sand (wt/wt) as the basis of the calculations. The Sevin was dissolved in $25 \mathrm{ml}$ of methanol, then added to $100 \mathrm{ml}$ of Modified Shive's Nutrient Solution (Table 1). The solution was added to the moist sand and mixed on heavy brown paper for 15 minutes. The control sand was prepared in the same manner as the treated sand (including $25 \mathrm{ml}$ of methanol), but no insecticide was added. The thoroughly mixed sand was then transferred to $5 \times 8 \mathrm{~cm}$ plastic pots and three marked seedlings were planted in each pot. The pots were placed in the scherer growth chamber, under the same environmental conditions used for germination, for a period of 10 days. Three treated plants and three control plants were harvested every other day to determine the effects of sevin on the plants. The experiment was terminated at 10 days and the plants harvested on the 10th day were the primary source of the experimental data.

\section{Microtechnique}

The harvested plants were measured and placed in Modified Shive's Nutrient Solution for 5 minutes. The primary root was cut $1.0 \mathrm{~cm}$ from the root apex and was wrapped in cotton gauze and placed into Craf III fixative 
Table 1. Modified Shive's Nutrient Solution.

Chemical Compound

Concentration $\mathrm{mg} / 1$

$\mathrm{KH}_{2} \mathrm{PO}_{4}$

1.0

$\mathrm{MgSO}_{4} \cdot 7 \mathrm{H}_{2} \mathrm{O}$

2.0

$\mathrm{Ca}\left(\mathrm{NO}_{3}\right)_{2} \cdot 4 \mathrm{H}_{2} \mathrm{O}$

5.0

$\mathrm{K}_{2} \mathrm{SO}_{4}$

2.0

$\mathrm{B}$ as $\mathrm{H}_{3} \mathrm{BO}_{3}$

0.1

$\mathrm{Fe}$ as $\mathrm{FeSO}_{4} \cdot 7 \mathrm{H}_{2} \mathrm{O}$

0.5

$\mathrm{Mn}$ and $\mathrm{Cl}$ as $\mathrm{MnCl}_{2} \cdot 4 \mathrm{H}_{2} \mathrm{O}$

0.23

$\mathrm{Cu}$ as $\mathrm{CuSO}_{4} \cdot 5 \mathrm{H}_{2} \mathrm{O}$

0.01

Mo as $\mathrm{NaMOO}_{4} \cdot 2 \mathrm{H}_{2} \mathrm{O}$

0.1

$\mathrm{Zn}$ as $\mathrm{ZnSO}_{4} \cdot 7 \mathrm{H}_{2} \mathrm{O}$

0.1 
( $1 \%$ chromic aaid $(30 \mathrm{ml}), 37 \%$ formaldehyde (10 ml), 10\% acetic acid $(20 \mathrm{ml})$ and distilled water $(40 \mathrm{ml}))$. The tissues were fixed for 24 hours, then washed under a steady stream of tap water to remove the fixative. The roots were dehydrated in an ascending series of ethanol-tertiary butyl alcohols (20\%, 50\%, 75\% 96\% (2 changes), 100\% (2 changes) and t-butyl alcohol ( 2 changes) at one-hour intervals. The roots were then transferred to a solution of $\frac{3}{2}$ paraffin and $\frac{1}{2}$ t-butyl alcohol in a $55^{\circ} \mathrm{C}$ oven for $6-12$ hours. They were transferred to pure paraffin (m.p. 530 C) for 12-24 hours ( 3 changes of paraffin within this period). The same procedure was repeated in a $5^{\circ} \mathrm{C}$ oven in Paraplast (Sherwood Industries) $\left(\mathrm{m} . \mathrm{p} \cdot 56-57^{\circ} \mathrm{C}\right)$. The roots were then embedded in metal boats with connecting plastic rings which were appropriately labelled.

Logitudinal and cross sections were cut $5 \mathrm{~km}$ thick on a Spencer 820 rotary microtome. The sections were floated on a heated water bath $\left(35^{\circ} \mathrm{C}\right)$, to which a small quantity of gelatin had been added, and then transferred to glass slides. The slides were placed in a $55^{\circ} \mathrm{C}$ oven for one hour and allowed to cool until ready for hydration. A descending series of xylene-ethanol alcohols brought the sections to proper hydration. The slides were then stained in $0.2 \%$ aqueous Safranin for 3 hours, washed in tap water, and then stained in Harris' Hematoxylin for 6 minutes. The sections were again washed in tap water and transferred via an ascending alcohol series to alcoholic Fast Green $0.2 \%$ 
in $95 \%$ alcohol) for 10 seconds. The stain was differentiated in 95\% alcohol for 2 changes ( 10 quick dips). The sections were dehydrated to xylene at 3-minute intervals and mounted with Tissue Mount (Harleco Science Industries) and observed microscopically. These histological techniques were modifications from Sass (1958).

Colorimetric Determination of Insecticide Application

The method of Johnson et al. (1963) was used to determine the actual Sevin concentration at the beginning and end of the experiments. A sample of $2.5 \mathrm{~g}$ of treated sand was extracted with approximately $20 \mathrm{ml}$ of methanol. The total volume was collected to obtain $20 \mathrm{ml}$ of the extracted insecticide-methanol-water solution. The solution was filtered through No. 4 Whatman filter paper to eliminate extraneous materials. Two milliliters of a $1 \mathrm{~N} \mathrm{NaOH}$ solution was added to $5 \mathrm{ml}$ of the filtered solution and allowed to react for 5 minutes to complete the hydrolysis of Sevin to 1-naphthol. The hydroxylated solution was diluted with $17.0 \mathrm{ml}$ of glacial acetic acid followed by the addition of $1.0 \mathrm{ml}$ of p-nitrobenzenediazonium fluoborate which reacts with the 1-naphthol to produce a colored material. A deep yellow color after 15 minutes represented maximum absorbance. This color fades slowly after 1 hour because of a rapid breakdown of the p-nitrobenzenediazonium fluoborate-1-naphthol complex. A spectronic 20 was used to determine the absorbance at $475 \mathrm{~nm}$ after 15 minutes of color development. Optical density values for the onset 
(day 0) and termination (day 10) of each experiment were compared to a standard curve from which the appropriate concentration was determined in parts per million (Fig. A-l, Table A-1).

\section{Autoradiography}

Translocation of Sevin was determined by using ringlabelled ${ }^{14} \mathrm{C}$-Sevin obtained from the Ameshaw Searle Co. via Syracuse University, Syracuse, New York. Procedures used were described by Crafts and Yamaguchi (1964). Labelled Sevin $32.5 \mathrm{mi} / \mathrm{mg}$ specific activity was dissolved in acetone to approximately $5000 \mathrm{ppm}$ and a final volume of $1.4 \mathrm{ml}$.

For these experiments, the soybean plants were 45 days old. The plants were then transferred from sand into aerated Shives' Nutrient Solution (Fig.1.). For foliar applications Sevin was applied directly to the primary and trifoliate leaves. For root applications 4.8 ci were added to the nutrient solution. For primary and trifoliate leaf application, $1.6 \mu \mathrm{C} i$ were added over a midvein near the laminar base which had been ringed by lanolin to prevent dispersal of the radioactive insecticide on other plant surfaces. After two days exposure, gross autoradiographs were prepared (according to Crafts and Yamaguchi (1964)).

A radioassay to determine the amount of radioactive Sevin present in specific parts of the plants was also made. This was done by dissecting and grinding each plant part (i.e., roots, stem above treated leaf or leaflet, stem below 
treated leaf or leaflet, treated leaf or leaflet, all leaves minus treated leaf or leaflet and pods) and placing $100 \mathrm{mg}$ of the pulverized dry tissue into metal planchets. The planchet was placed into an automated planchet counter (Tracer Lab Counter) and the time required to register 1000 counts were recorded.

After correction for background and self absorption errors, the $14 \mathrm{C}$-content was calculated as specific activity (cts/min/mg). 
16.

Fig. 1. Experimental design for treatment of soybeans with 14c-Sevin. 


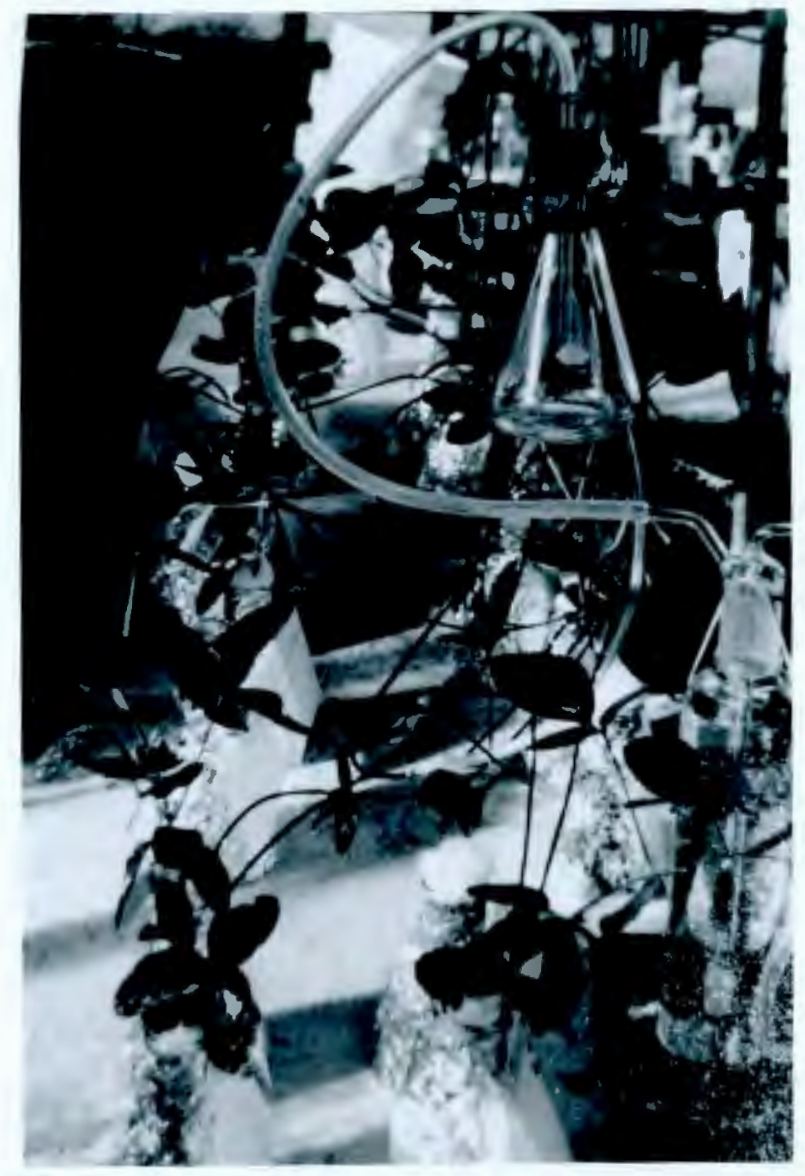




\section{RESULTS}

MORPHOLOGICAL OBSERVATIONS

A morphological description of each soybean plant was recorded at each harvest. Observations included various aspects of the overall development of soybeans, i.e., pigmentation of hypocotyl and epicotyl, cotyledon expansion, primary and trifoliate leaf expansion (Table 2). In general, plants harvested on day 10 formed the basis for the following observations.

Effects on Cotyledons

All Sevin concentrations retarded complete expansion of the cotyledons by 2 days. A difference in the size of the cotyledons was observed in relation to increasing Sevin concentrations, 1.e., cotyledons of the $55 \mathrm{ppm}$ plant were smaller than those of the $25 \mathrm{ppm}$ plant, etc. (Figs. 2, 3). Effect on Hypocotyl and Epicotyl

Pigment, presumably anthocyanin, was conspicuously absent from all treated plants. The hypocotyl and epicotyl remained light green. Although not directly measured, the hypocotyl and epicotyl of the treated plants showed a visible decrease in length as Sevin concentration increased (Figs. 2, 3).

Effect on Primary and Trifoliate Leaf Expansion

Emergence of primary leaves was delayed with increased Sevin concentrations (Table 2).

Emergence of trifoliate leaves did not occur at all concentrations of Sevin used (Figs. 2, 3). Above $21 \mathrm{ppm}$ of 
Table 2. Morphological observations of soybean growth versus Sevin concentrations.

Amount of Sevin applied, ppm

$\begin{array}{lllllll}0 & 2 & 9 & 19 & 21 & 25 & 55\end{array}$

Day 2

Pigmentation of hypocotyl

Cotyledon expanded

Primary leaf expansion

Secondary leaf expansion

Lateral root emergence

$\begin{array}{lllllll} \pm & - & - & - & - & - \\ \pm & - & - & - & - & - & - \\ \pm & - & - & - & - & - & -\end{array}$

Daj 4

Pigmentation of hypocotyl

Cotyledon expanded

Primary leaf expansion

Secondary leaf expansion

Lateral root emergence

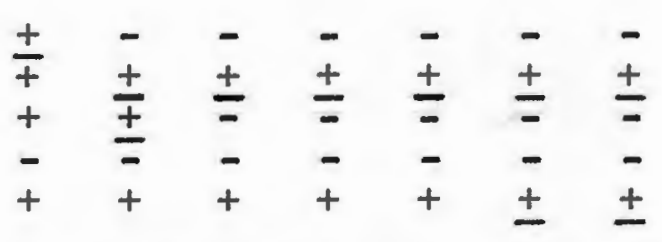

Day 6

Pigmentation of hypocotyl

Cotyledon expanded

Primary leaf expansion

Secondary leaf expansion

Lateral root emergence

$\begin{array}{lllllll}+ & - & - & - & - & - & - \\ + & + & + & + & + & + & + \\ + & + & + & + & + & - & - \\ + & - & - & - & - & - & - \\ + & + & + & + & + & + & +\end{array}$

Day 8

Pigmentation of hypocotyl

Cotyledon expanded

Primary leaf expansion

Secondary leaf expansion

Lateral root emergence

$\begin{array}{lllllll}+ & - & - & - & - & - & - \\ + & + & + & + & + & + & + \\ + & + & + & + & + & - & - \\ + & - & - & - & - & - & -\end{array}$

ग्रूप 10

Pigmentation of hypocotyl

Cotyledon expanded

Primary leaf expansion

Secondary leaf expansion

Lateral root emergence

$\begin{array}{lllllll}+ & - & - & - & - & - & - \\ + & + & + & + & + & + & + \\ + & + & + & + & + & + & \pm \\ + & \pm & - & - & - & \overline{1} & =\end{array}$

+ Plant has characteristic

- Plant does not have characteristic

\pm Plant shows partial characteristic 
Fig. 2. A) Soybean plants treated with 0,9 and $19 \mathrm{ppm}$ of Sevin. Note lack of anthocyanin in epicotyl and hypocotyl and overall decrease of plant growth of treated soybeans. Note that the roots are thin with numerous lateral roots when compared to the controls. Foliar expansion is impared.

B) Soybean plants treated with 0,25 and $55 \mathrm{ppm}$ of Sevin. Note dramatic difference in plant growth at 25 and $55 \mathrm{ppm}$ Sevin. Anthocjanin production in the hypocotyl and epicotyl is absent. Roots are short and thin. Note delays in foliar expansion. An obvious purple discoloration of roots is evident at 25 and $55 \mathrm{ppm}$. 

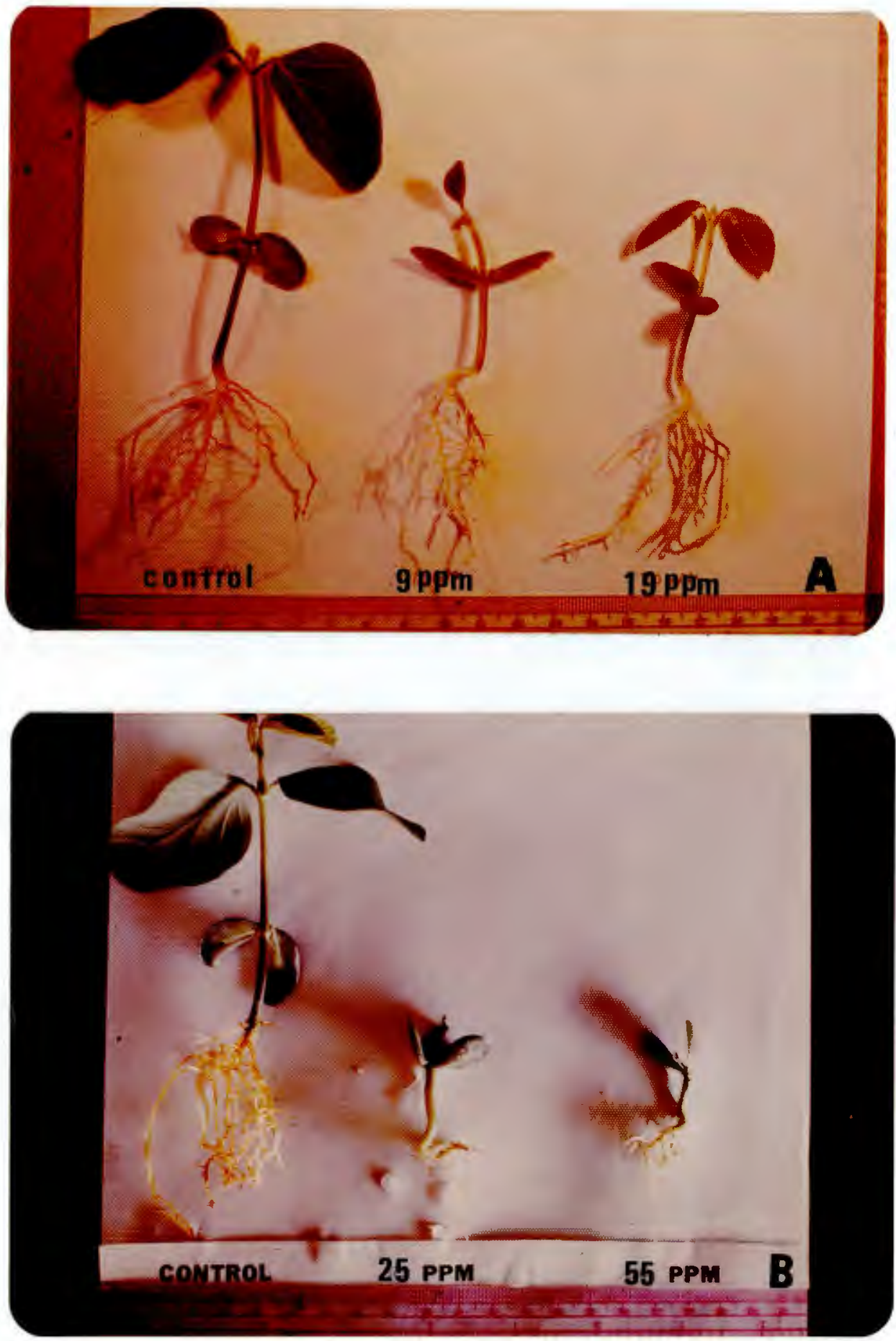
Fig. 3. Soybean plants treated with 0,21 and 2 ppm of Sevin. Notice lack of anthocyanin in hypocotyl and epicotyl. There is a delay of follar expansion and proliferation of lateral roots at $21 \mathrm{ppm}$. At $2 \mathrm{ppm}$ Sevin, there appears to be little effect on the soybean plant growth. 
23.

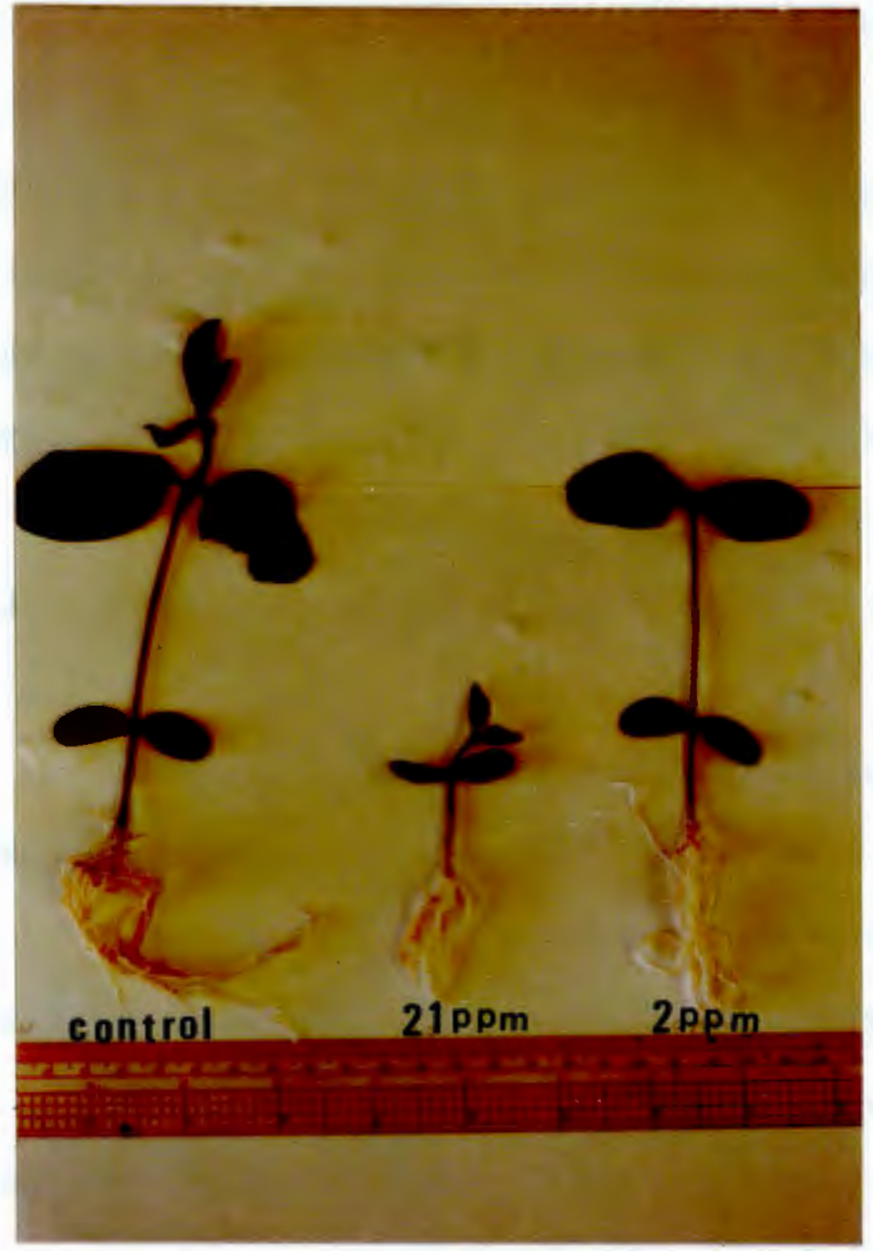


Sevin, the trifoliate leaves did not develop, although primordia were present (Figs, 2, 3).

Effect on Root

With increased concentrations of Sevin, both tap roots and lateral roots exhibited marked difference in size and number rather than difference in the day of emergence. The roots were white and thin in comparison with the control roots (Figs. 2, 3). Many of the lateral roots emerged only a short distance from the root apex, and this distance decreased with increased concentrations of Sevin. At lower concentrations of Sevin, the lateral roots were longer and more prolific than at higher concentrations. After 10 days growth, the tap roots and lateral roots contained a purple pigment at 9, 19, 21, 25 and $55 \mathrm{ppm}$ of Sevin.

Analyses of the root length data, i.e., growth of the root tip in relation to an ink mark $1.0 \mathrm{~cm}$ from the tip, are presented in Figs. 4 and 5. A study conducted to 1llustrate possible effects of Sevin on the distance from the root apex to the cotyledons, showed after analysis, that the data reflected the same general patterns as the data derived from the measurement of root tip growth in relation to an ink mark $1.0 \mathrm{~cm}$ from the root apex.

The graphs represent a general trend of inhibition of root tip growth and lateral root emergence with increasing concentrations of Sevin. Analysis of variance performed on the data showed significant differences at the $1 \%$ level. 
A Duncan's Modified Multiple Range Test (Steel and Torrie, 1969) was calculated to determine where the significant differences had occurred (Table 3). Root tip growth of plants treated with 2, 9 and $19 \mathrm{ppm}$ was not significantly different from the controls, but root growth was significantIy inhibited in plants treated with 21,25 and $55 \mathrm{ppm}$ of Sevin. It would appear that the threshold concentration for inhibition of root tip growth by Sevin is between 19 and $21 \mathrm{ppm}$. The emergence of lateral roots paralleled the statistical analysis except that the threshold for Sevin concentration is between 21 and $25 \mathrm{ppm}$. RADIOASSAY OBSERVATIONS

The symplast consists of the interconnected living elements of plants (e.g., protoplasm) while the apoplast is the nonliving portion of plants $(e \cdot g \cdot$, intercellular spaces, xylem vessels). "Specific Activity"(corrected counts per minute $\div$ weight of sample) and "Total Activity" (specific activity $X$ sample weight) were computed and used to derive percent distribution values (individual plant part total activity $\div$ of total activity for the entire plant) of ${ }^{14} \mathrm{C}$-Sevin applied to various plant organs (Fig, 6 , Table 4).

When $4.8 \mu \mathrm{Ci}$ of ${ }^{14} \mathrm{C}$-Sevin were applied to root tissues, $64 \%$ of the radioactivity was translocated into primary and trifoliate leaves. The roots, stems and pods received $36 \%$ of the ${ }^{14} \mathrm{C}$-Sevin. Autoradiographs suggest that the uptake of $14 \mathrm{c}$-Sevin was due to primarily to apoplastic movement, 
26.

Fig. 4. Root tip growth at various concentrations of Sevin. 
27.

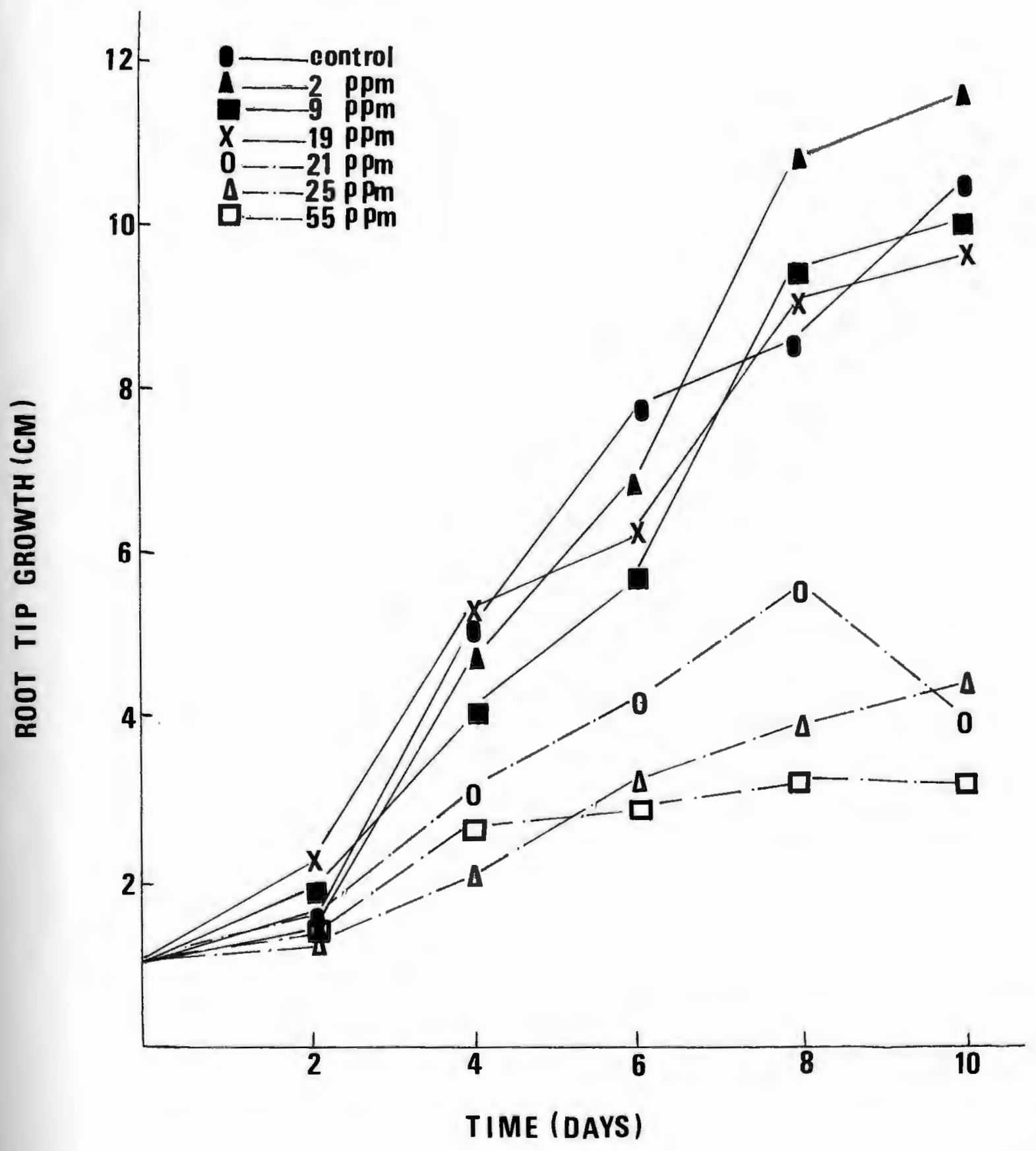


28 .

Fig. 5. Distance from root apex to zone of lateral root emergence at various concentrations of Sevin. 


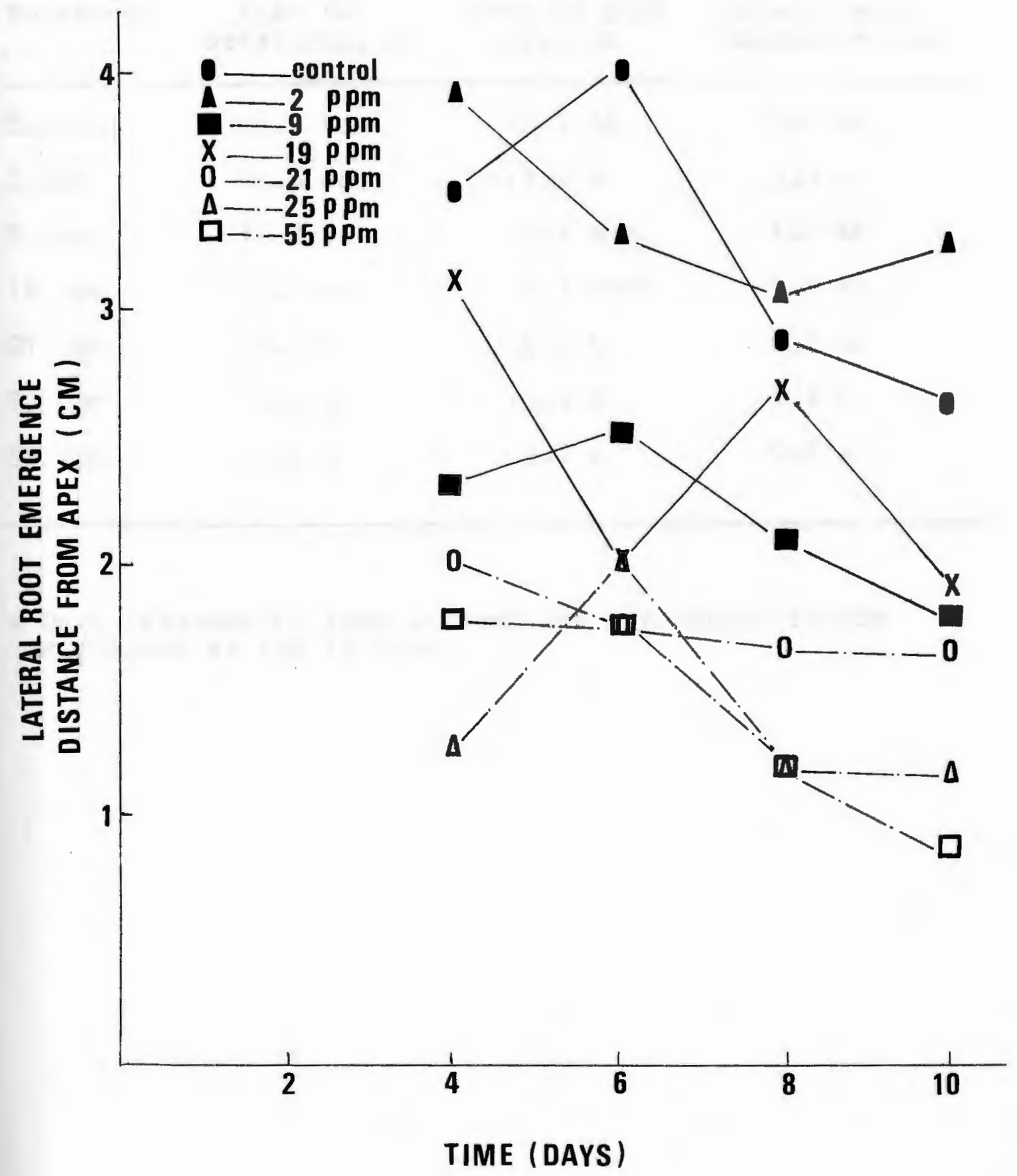


Table 3. Analysis of root growth data (Day 10) using Duncan's Multiple Range Test.

\begin{tabular}{lccc}
\hline Treatment & $\begin{array}{c}\text { Apex to } \\
\text { cotyledon, cm }\end{array}$ & $\begin{array}{c}\text { Mark to root } \\
\text { apex, cm }\end{array}$ & $\begin{array}{c}\text { Lateral root } \\
\text { emergence, cm }\end{array}$ \\
\hline Control & $14.1 \mathrm{bc} *$ & $13.3 \mathrm{de}$ & $2.6 \mathrm{bc}$ \\
$2 \mathrm{ppm}$ & $14.5 \mathrm{~cd}$ & $11.5 \mathrm{e}$ & $3.3 \mathrm{c}$ \\
$9 \mathrm{ppm}$ & $12.8 \mathrm{bc}$ & $9.9 \mathrm{cde}$ & $1.8 \mathrm{ab}$ \\
$19 \mathrm{ppm}$ & $11.5 \mathrm{bc}$ & $9.3 \mathrm{bcde}$ & $1.9 \mathrm{ab}$ \\
$21 \mathrm{ppm}$ & $6.5 \mathrm{a}$ & $4.4 \mathrm{a}$ & $1.7 \mathrm{ab}$ \\
$25 \mathrm{ppm}$ & $6.9 \mathrm{a}$ & $4.4 \mathrm{a}$ & $1.2 \mathrm{a}$ \\
$55 \mathrm{ppm}$ & $5.1 \mathrm{a}$ & $3.2 \mathrm{a}$ & $0.8 \mathrm{a}$
\end{tabular}

* Data followed by same letters are not significantly different at the 1\% level. 
Table 4. Specific activity, total activity and percent distribution of $14 \mathrm{C}-\mathrm{Sevin}$ in soybean roots, stems, leaves and pods.

\begin{tabular}{llrrr}
$\begin{array}{c}\text { Application } \\
\text { site }\end{array}$ & $\begin{array}{c}\text { Plant part } \\
\text { analyzed }\end{array}$ & $\begin{array}{r}\text { Specific } \\
\text { activity } \\
\text { cpm/mg }\end{array}$ & $\begin{array}{c}\text { Total } \\
\text { activity } \\
\text { cpm }\end{array}$ & $\begin{array}{c}\text { Distribution } \\
\%\end{array}$ \\
\hline Root & Roots & 559 & 33543 & 16 \\
& Stem & 176 & 33508 & 16 \\
& Leaves & 265 & 136601 & 64 \\
Pods & 19 & 8180 & 4 \\
Trifoliate & Roots & 25 & 1225 & 2 \\
leaf & Stem abovea & 7 & 599 & 1 \\
& Stem belowb & 10 & 7521 & 12 \\
& Leavesc & 9 & 7784 & 13 \\
& Treated leaf & 1051 & 41974 & 70 \\
Primary & Pods & 8 & 1257 & 2 \\
leaf & Roots & 9 & 677 & 1 \\
& Stem abovea & 42 & 6379 & 5 \\
& Stem below & 114 & 9211 & 8 \\
& Leavesc & 56 & 37337 & 31 \\
& Treated leaf & 1570 & 57966 & 49 \\
& Pods & 23 & 7331 & 6 \\
\hline
\end{tabular}

a Stem above treated leaf or leaflet

b Stem below treated leaf or leaflet

c All leaves except treated leaf or leaflet 
32.

Fig. 6. Percent distribution of ${ }^{14} \mathrm{C}$-Sevin to various parts of soybean plants. 


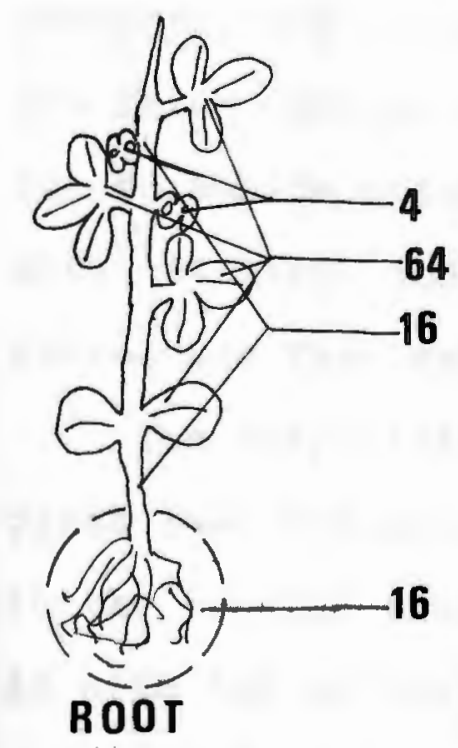

APPLICATION

$4.8(\mu \mathrm{Cl})$

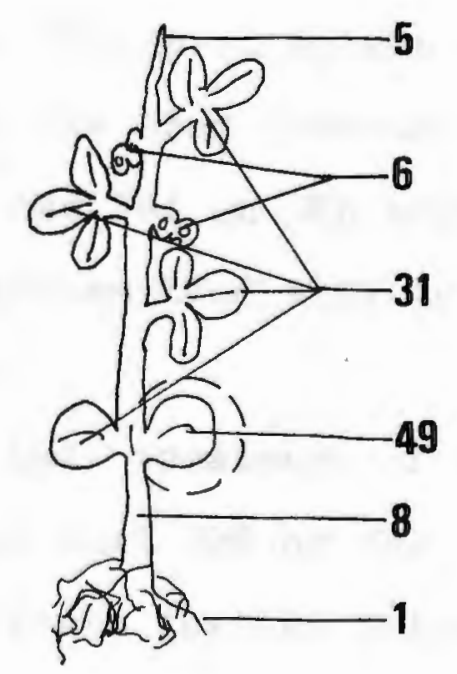

PRIMARY LEAF

APPLICATION

$1.6(\mu \mathrm{CI})$

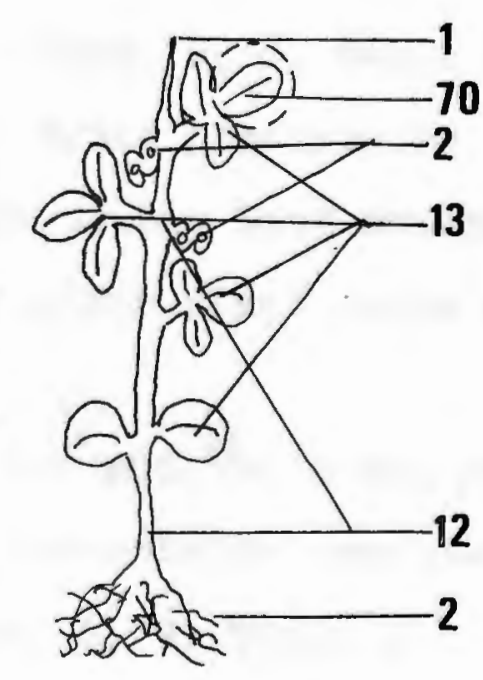

TRIFOLIATE LEAF

APPLICATION

$1.6\left(\mu C_{1}\right)$ 
since very little ${ }^{14} \mathrm{C}$-Sevin was translocated to the meristematic areas of the soybean (i.e., shoot and root apices and pods) (arrows in Fig. 7). There appeared to be some concentration of the ${ }^{14} \mathrm{C}$-Sevin in the symplast, but true symplastic movement is doubtful.

The primary leaf treatment of $1.6 \mu \mathrm{Cl}^{14} \mathrm{C}$-Sevin per plant showed that $49 \%$ of the radioactivity remained on the treated leaf with the next higher percentage in the other leaves (31\%). The roots, stems and pods accounted for the remaining 20\% of the $14 \mathrm{C}$-Sevin uptake (Figs. 6, 8, Table 4). The faint outline of the stem (arrows) could possibly be due to aphids which had fed on the area of the leaf treated with $14 \mathrm{C}-$-Sevin and transmitted this to other plant parts at subsequent feedings.

The trifoliate leaf treatment of $1.6 \mu \mathrm{Ci} 14 \mathrm{C}$-Sevin per plant leaf determined that $70 \%$ of the insecticide remained in the treated trifoliate leaflet (Figs. 6, 9, Table 4). As with the primary leaf treatment, the other leaves received $13 \%$, while the remaining $17 \%$ of the ${ }^{14} \mathrm{C}$-Sevin might be attributed to insect transport (arrows). The evidence suggests that no symplastic movement had taken place since the meristematic areas $(m)$ were deviod of labelled ${ }^{14} \mathrm{C}$-sevin. ANATOMICAL ANALYSES

For purposes of discussion, the description of the tissue systems in the root tips of Glycine max are discussed as follows: 1) Quiescent center, 2) Root cap and epidermis, 3) Cortex and 4) Vascular eylinder. 
Fig. 7. A) Autoradiggraph following the application of $4.8 \mu \mathrm{C} i \mathrm{CC}-$ Sevin to the nutrient solution. Arrow notes the possible apoplastic movement of the 14c-Sevin.

B) Autoradiograph enlargement of the trifolfate leaf. Arrows note lack of translocated $4 \mathrm{C}-$ Sevin into meristematic areas, indicating apoplastic movement. 
36.
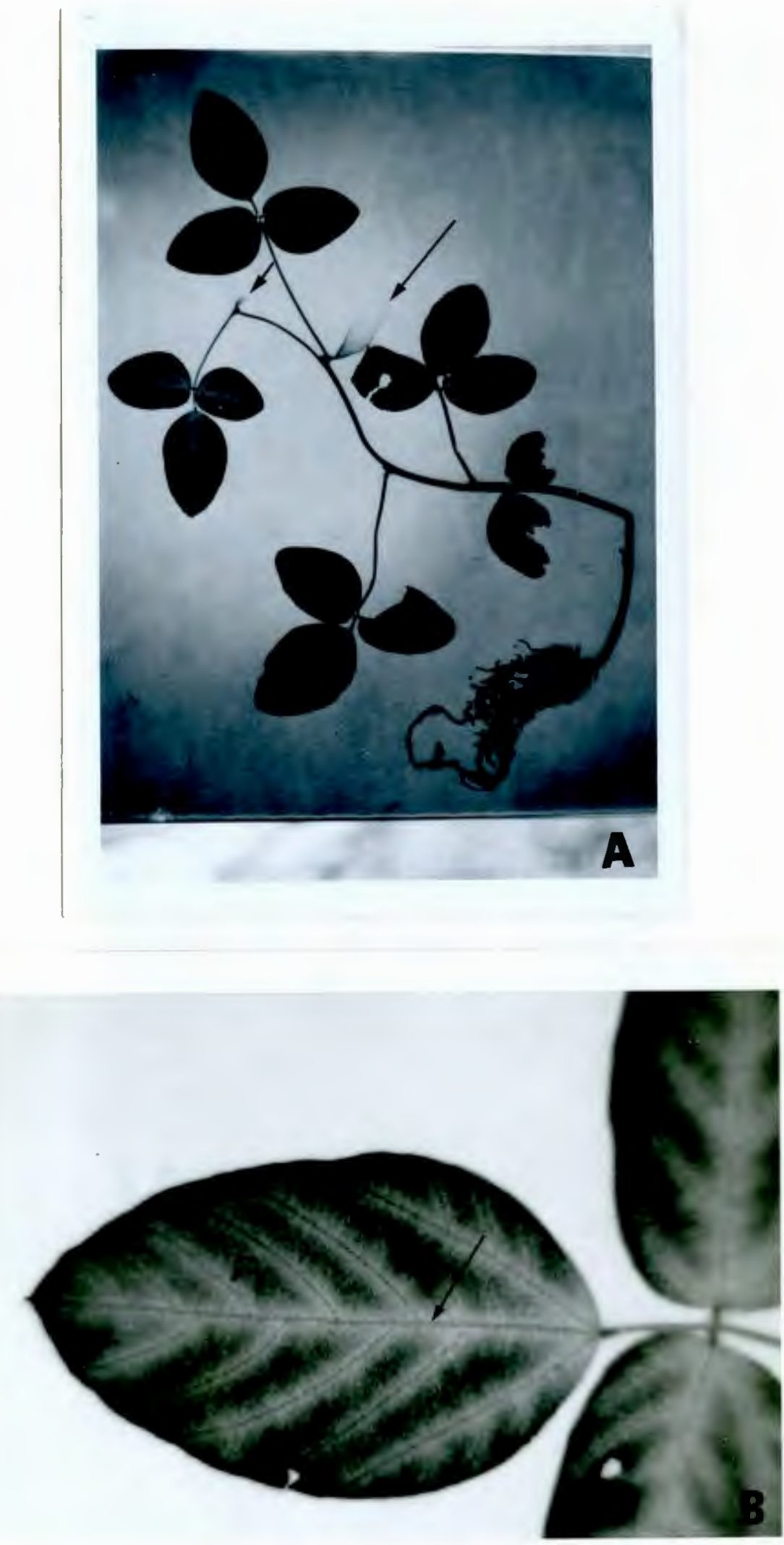
Fig. 8. A) Application site (arrow) of $1.6 \mathrm{uCi}^{14} \mathrm{C}$-Sevin to the primary leaf.

B) Autorpdiograph following the application of 1.6 $\mathrm{MC} i \mathrm{4C}-$ Sevin to the primary leaf. Arrows note possible translocation routes. Meristematic areas are labelled as (m). 
38.
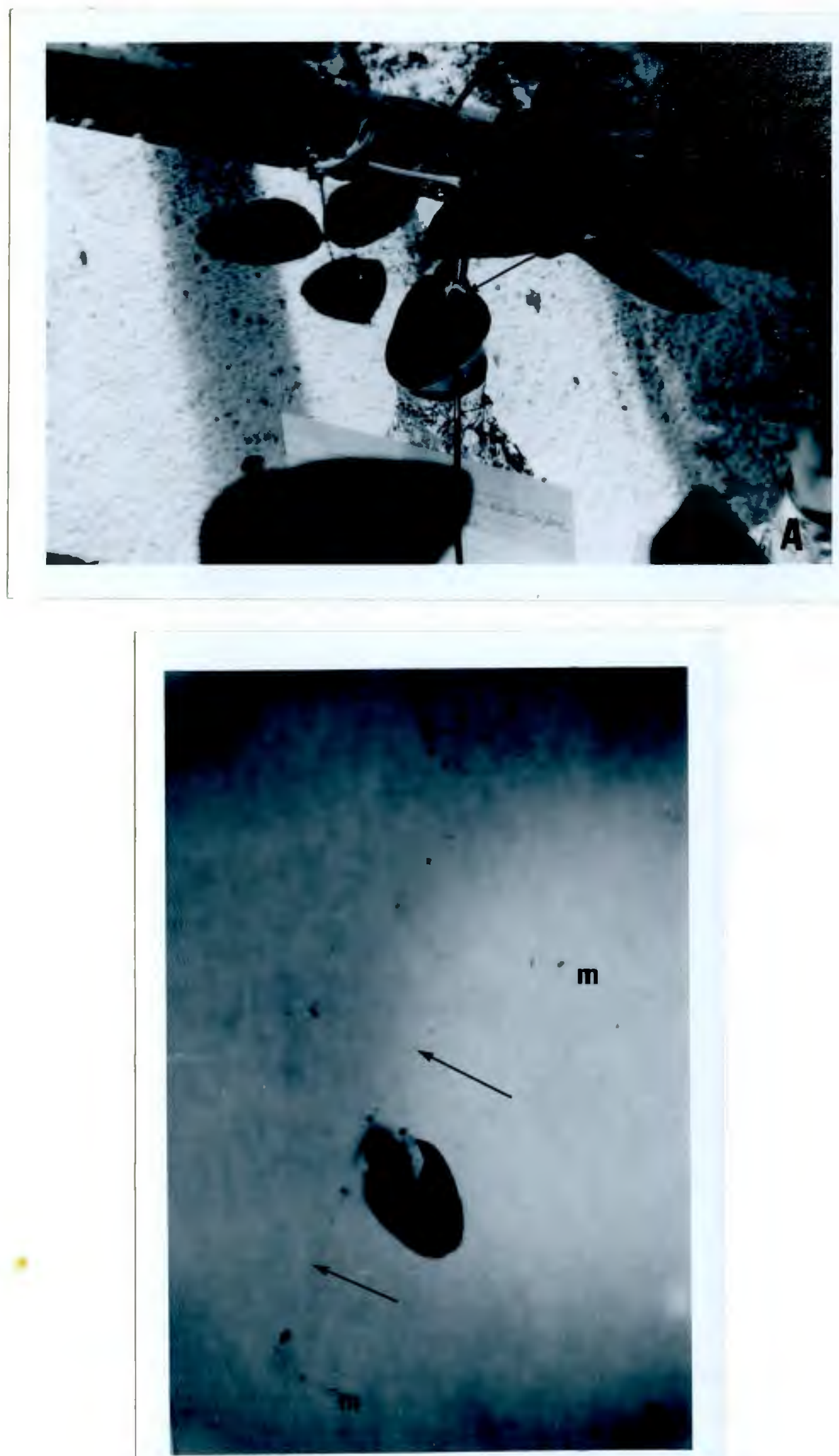
Fig. 9. A) Application site (arrow) of $1.6 \mu \mathrm{Ci}{ }^{14} \mathrm{C}$-Serin to the trifoliate leaf.

B) Autoradiograph following the application of 1.6 $\mu_{1}{ }^{4} 4$-Sevin to the trifoliate leaf. Arrows note possible translocation routes. Meristematic areas are labelled as $(m)$. 
40.
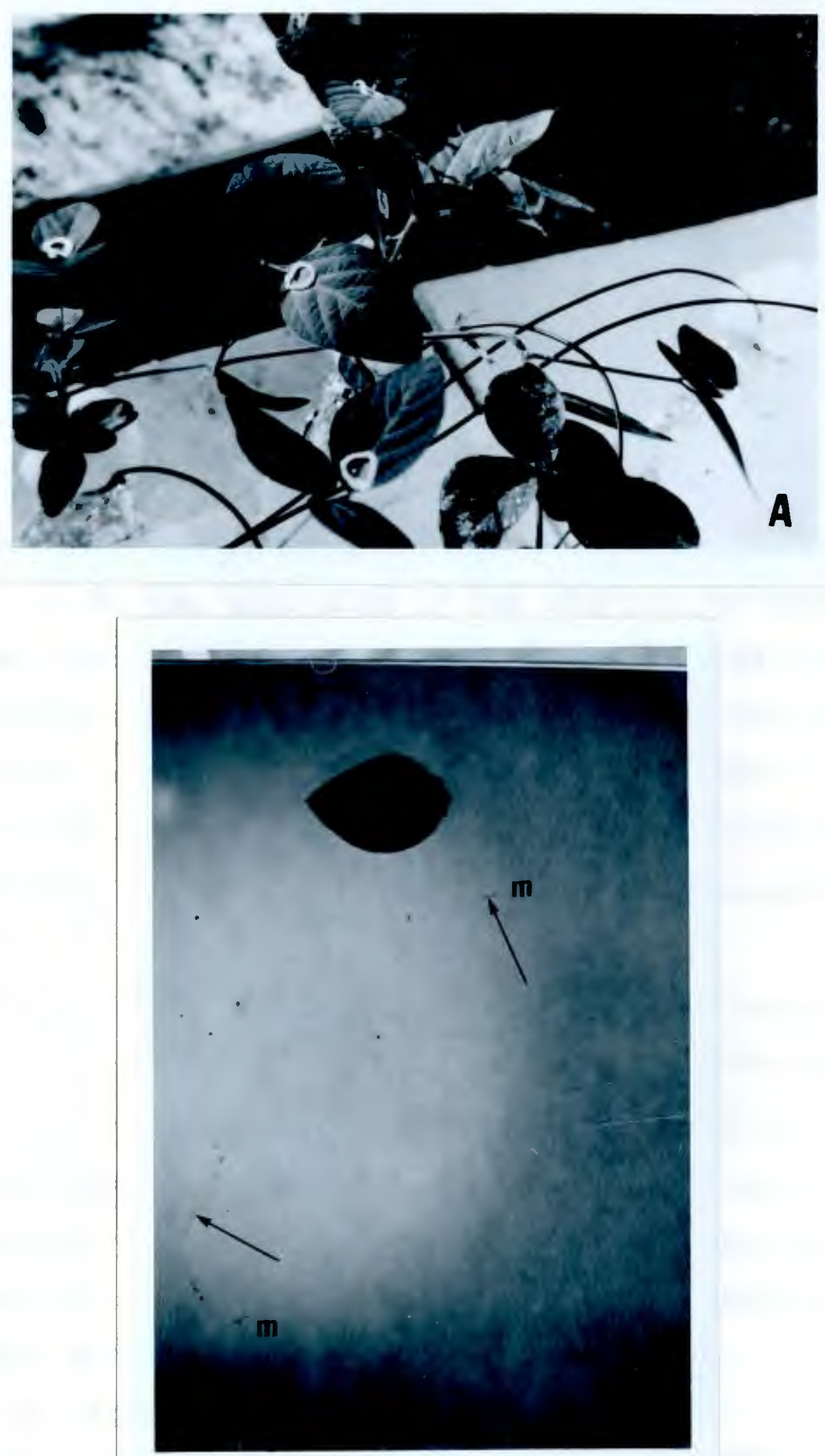
The Effects of Sevin on the Quiescent Center

Examination of the quiescent center of the plants treated with 2, 9 and $19 \mathrm{ppm}$ of Sevin revealed little or no appreciable differences from the control (Fig 10). The quiescent centers of plants treated with 21,25 and 55 ppm did not appear appreciably different from the controls, although the hemispherical outline of the quiescent centers was somewhat less well defined than those of the controls (Figs. 11, 13).

The Effects of Sevin on the Root Cap and Epidermis

The root cap was not affected at 2,9 and $19 \mathrm{ppm}$ of Sevin. At $21 \mathrm{ppm}$, hypoplasia of the root cap and epidermal tissues, prevlously reported by Lichtenstein et al. (1962), was observed (Fig. 11). In many instances, the root cap was partially sloughed off or was campletely absent. The cells of the root cap appeared to be more compressed than those of the controls and were also rounded in appearance (Fig. 11).

The epidermis exhibited no change from the controls at 2, 9 and 19 ppm Sevin. The epidermis of plants treated with 21,25 and $55 \mathrm{ppm}$ of Sevin presents a flattened roughened area against the cortex. A purple pigment was noticed on the epidermis of the root. When the tissue was processed, the color was lost and only the flattened appearance of the epidermal tissue remained.

Effect of Sevin on the Cortex

The cortex at treatments 2,9 and $19 \mathrm{ppm}$ exhibited no 
difference from the controls while at 21,25 and $55 \mathrm{ppm}$, a noticeable difference in structure had occurred.

At $21 \mathrm{ppm}$, the cells of the cortex were apparently compressed. At $25 \mathrm{ppm}$ the apical meristem was compressed and the cortex appeared to bulge out at approximately $300 \mathrm{zm}$ from the quiescent center (Fig. 12). The cortical cells at $55 \mathrm{ppm}$ were difficult to distinguish from the vascular oylinder (Fig. 13). The cells appeared shorter, more compressed and more vacuolate than in the controls. Effects of Sevin on the Vascular Cylinder

The vascular cylinder was affected primarily at higher dosages of Sevin. These caused an appearance of maturing tracheary elements and a development of lateral root primordia opposite the protoxylem poles close to the quiescent center. At 2, 9 and 19 ppm there were no readily observable differences between the treated roots and the controls. Higher dosages of 21, 25 and $55 \mathrm{ppm}$ of Sevin produced short, flat, maturing tracheary elements approxiamtely $300 \mathrm{\mu m}$ from the quiescent center (Figs. 11, 12). This suggests that the root apex did not advance before differentiation had taken place or differentiation occurs more rapidly than meristematic growth. Lichtenstein et al. (1962) labelled this process as a "growth inhibition".

A noticeable difference occurred in a wedge of cells opposite the four protoxylem poles at 12, 25 and $55 \mathrm{ppm}$ of Sevin (Fig. 13). Easu (1953) describes this proliferation of cells as the periclinal and anticlinal cell divisions of 
the lateral root primordia. These cells were present in both controls and treated plants, but at increased concentrations of Sevin, the primordia contained a larger number of cells. Their occurrence was probably related to an inhibition of cell elongation which produced lateral roots close to the quiescent center at 25 and $55 \mathrm{ppm}$ of Sevin. Other tissues in treated plants, including the phloem, endodermis and parenchyma in the vascular cylinder showed no change. 
44 .

Fig. 10. A) Iongitudinal section of the control root (100X). (vc) vascular cylinder; (imx) immature metaxylem cells; (qc) quiescent center; ( $r c$ ) root cap;

(c) cortex.

B) Cross section of control root (400X).

(en) endodermis; (pe) pericycle; (mx) metaxylem;

(px) protoxylem; (ph) phloem; (c) cortex; (Irp)

site of lateral root primordia. 

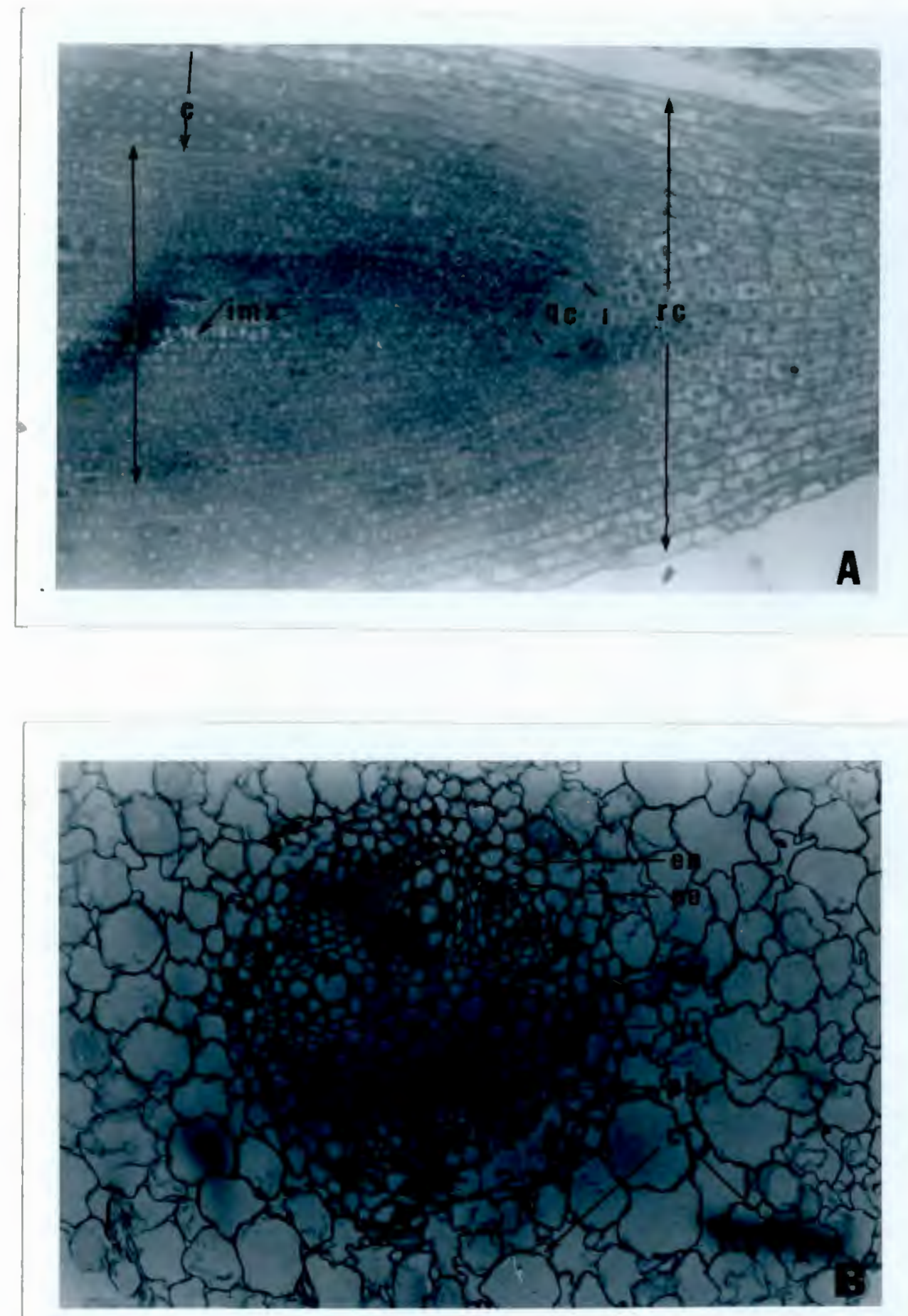
Fig. 11. A) Longitudinal section of root treated with 21 ppon of Sevin (100X). (rc) root cap; (qc) quiescent center; (vc) vascular cylinder; (c) cortex. The quiescent center (qc) is not distinctiy defined. A noticeable hypoplasia of the root cap ( $r c$ ) and compressed cortical tissues (c) are evident. The vascular cylinder (vc) reveals maturing tracheary elements close to the quiescent center.

B) Iongitudinal section of root treated with 21 ppm of Sevin (400X). (mte) maturing tracheary element; (c) cortex; (qc) quiescent center. Note maturing tracheary elements (mte) close to the quiescent center (qc) Note shortness of cortical cells (c). 

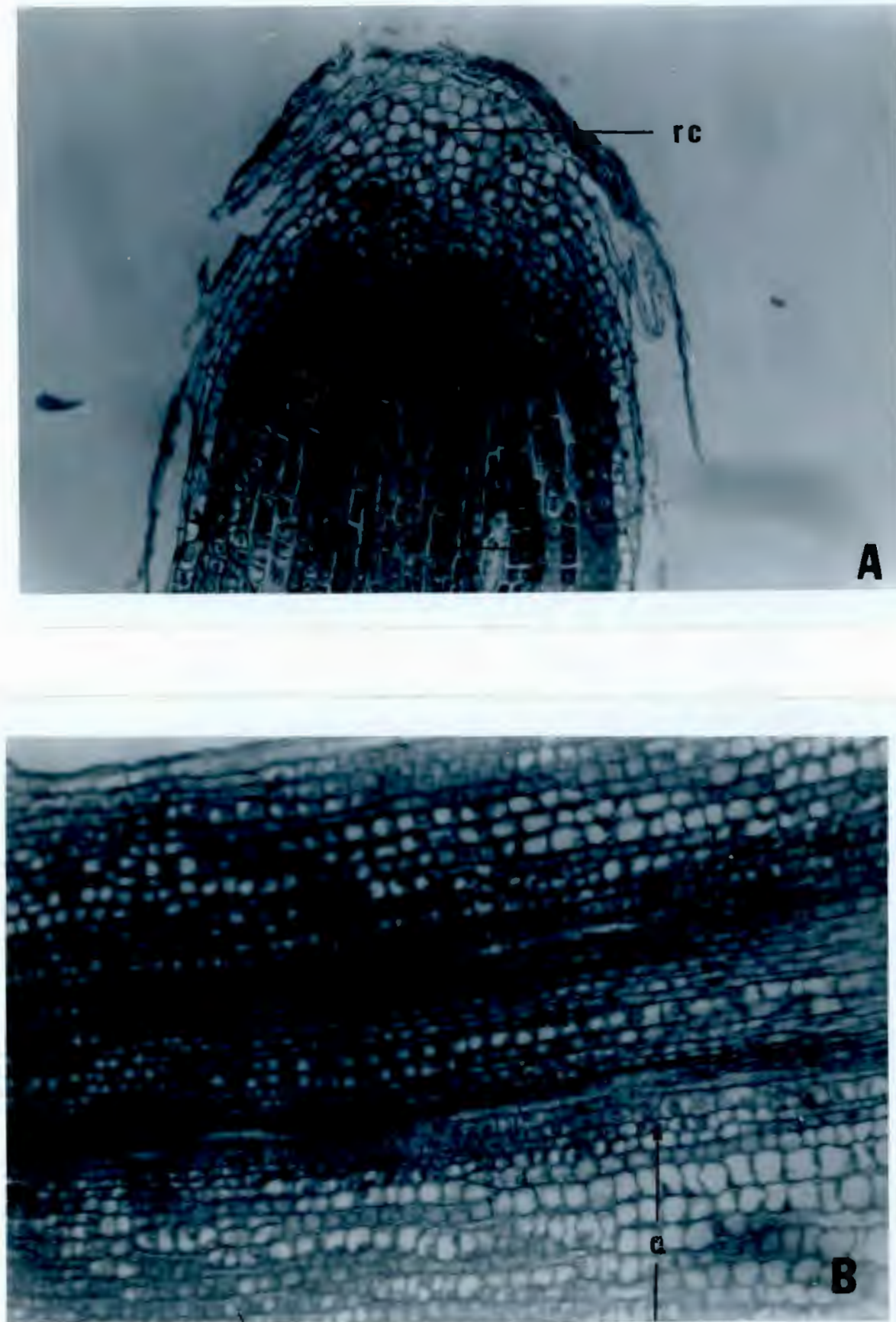
Fig. 12. A) Longitudinal section of root treated with 25 ppm of Sevin (400X). (c) cortex; (qc) quiescent center; (mte) maturing tracheary element. Note the maturing tracheary elements (mte) close to the compressed quiescent center (qc). The cortex (c) appears to bulge out approximately $300 \mathrm{xm}$ from the quiescent center.

B) Maturing tracheary element (1000X). 

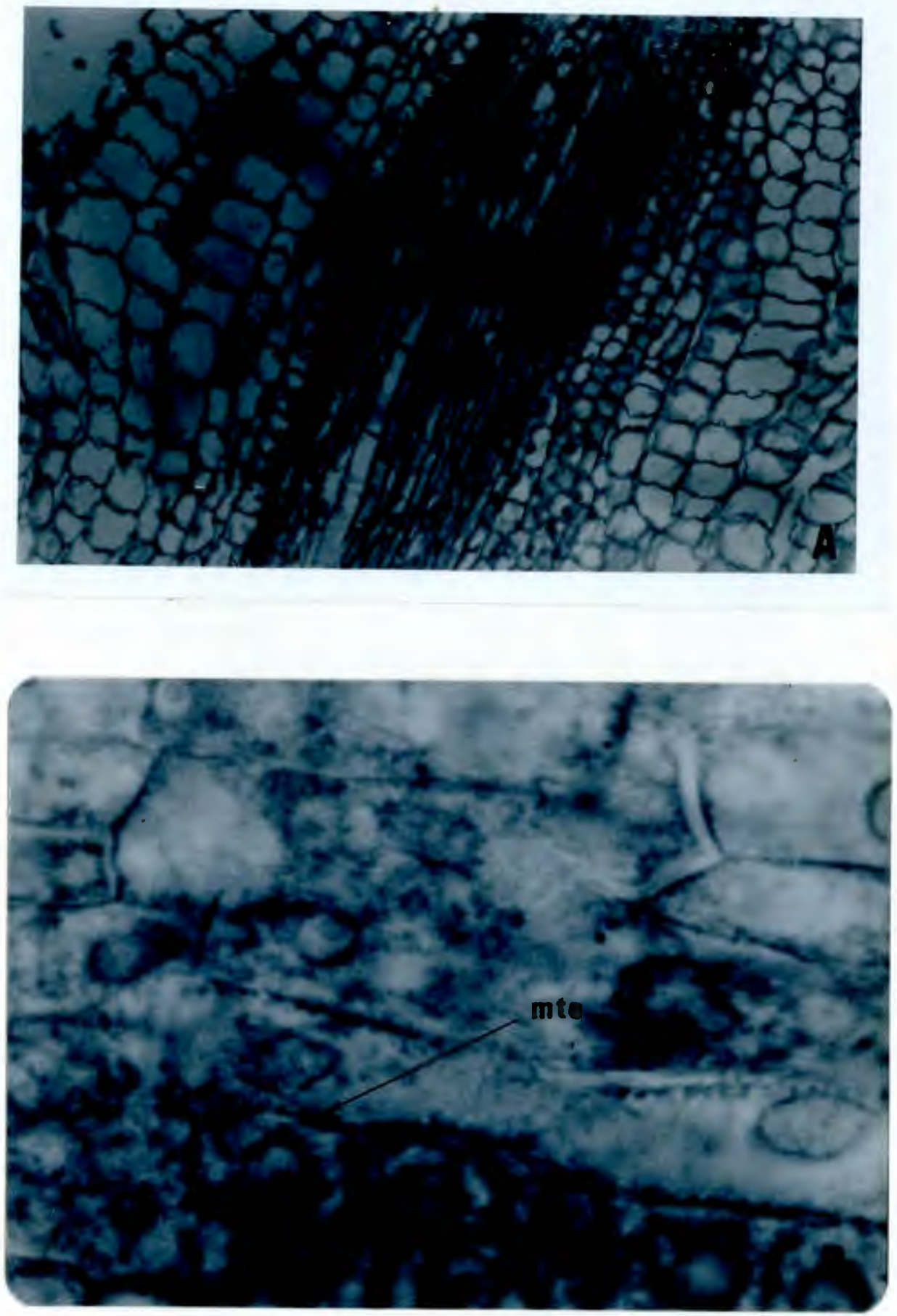
Fig. 13. A) Longitudinal section of root treated with 55 ppm of Sevin (100X).

(e) epidermis; (qc) quiescent center; (c) cortex; (vc) vascular cylinder; (rc) root cap. The normally hemispherical quiescent center (qc) and cortical tissues (c) are not clearly defined in relation to the vascular cylinder (vc). The epidermis (e) appears flattened and roughened against the cortex.

B) Cross section of root treated with $55 \mathrm{ppm}$ of Sevin (400X). (Irp) lateral root primordium; ( $p x$ ) protoxylem; (mx) metaxylem; (ph) phloem; (en) endodermis; (pe) pericycle. The lateral root primordia (Irp) opposite the protoxylem pole (px) are noticeably larger and appear much earlier in root development than the control (Fig. 10B). The other tissues appear quite normal in development (i.e., endodermis (en), pericycle (pe) and phloem (ph), metaxylem $(m x))$. 

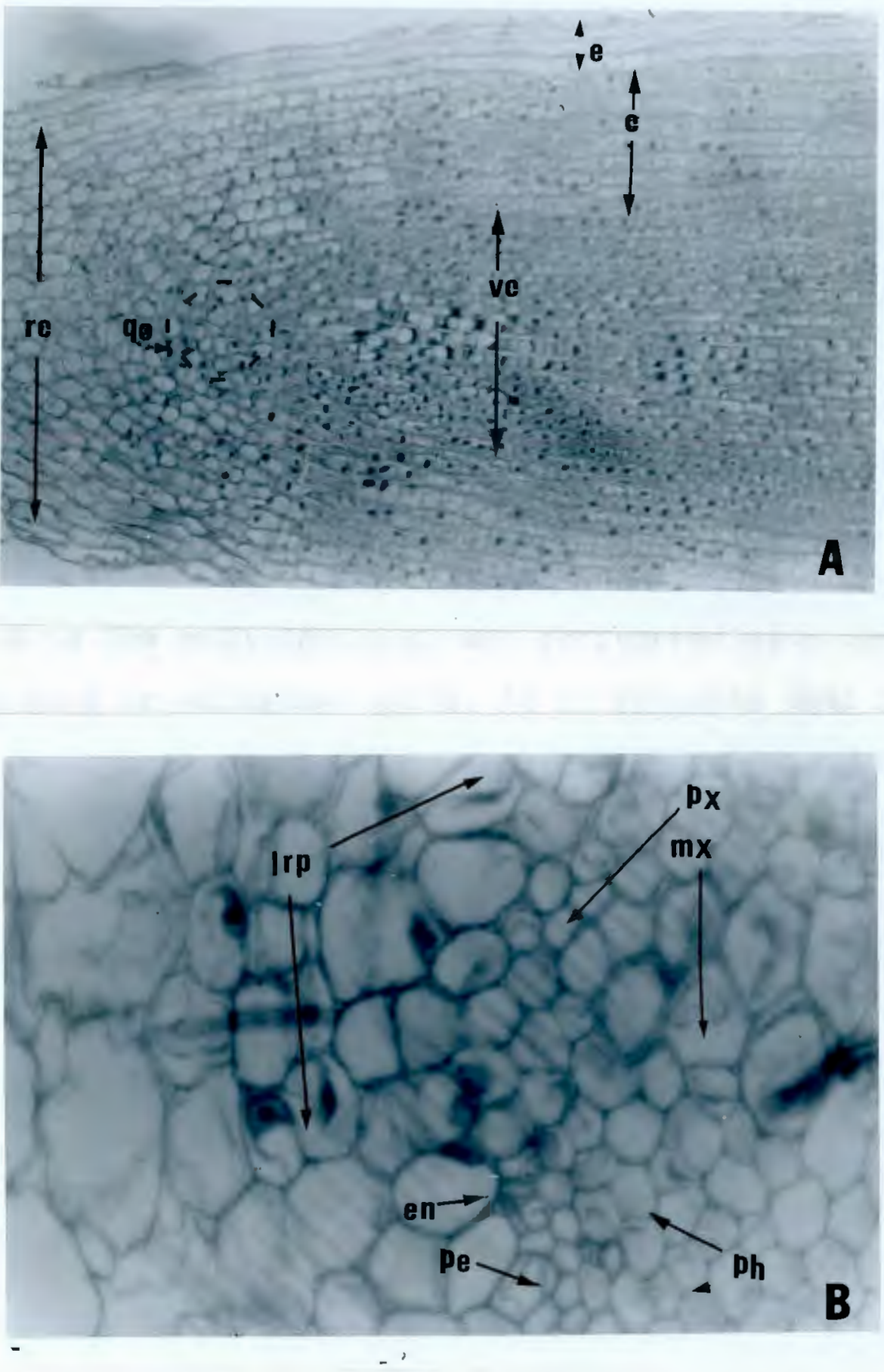


\section{DISCUSSION}

One of the most noticeable differences in the morphology of soybeans following the application of Sevin was the absence of pigment (presumably anthocyanin) which is normally present in the stem and hypocotyl.

Hydroxylation is the primary means of oxidation of Sevin (Kuhr, 1970). The hydrolysis of Sevin to its aromatic ring components, 1-naphthol, or to its $\mathbb{N}$-methyl carbamate group forms a "handle" for the conjugation of sugars, amino acids or other campounds. Thus, it can be postulated that the cleaving of Sevin by the enzyme B-glucosidase could yield a product that can "imitate" the basic structure of anthocyanins which are the anthocyanidins.

Since the anthocyanidins are conjugated with one or two glucose or galactose units, it is possible that the Sevin components could act as metabolic inhibitors to interrupt normal development of anthocyanin and be incorporated into the plant in place of the anthocyanins. The specific difference in structure of Sevin compounds could account for the fact that these compounds appear colorless. Anthocyanin production could also have been curtailed by the general disruption of normal metabolic processes when Sevin was introduced into the root environment. Possibly the Shikimic Acid Pathway, which produces the amino acids phenylalanine and tyrosine, could have been blocked by conjugation of the cleaved Sevin compound and the amino acids. The statistical analyses throughout the 
thesis indicated that there were no basic differences from controls either in morphology or root anatomy of soybeans at 2, 9 and $19 \mathrm{ppm}$ Sevin. However, at all concentrations of Sevin, anthocyanin was conspicuously absent in the stem and hypocotyl.

Lichtenstein et al. (1962) reported that the growth of corn and pea plants was noticeably affected at $30 \mathrm{ppm}$ of Sevin. In the research described here, the growth of soybeans was affected at concentrations beginning at 21 ppm. Reduction in growth was probably the result of many factors. One possibility could be a general slowdown of respiration and consequently of cell metabolism since any slowdown for any reason will likely reduce respiration. According to Lichtenstein et al. (1962) the respiration of corn and pea plants was reduced $28 \%$ to $54 \%$ in the uptake of oxygen per milligram dry weight per hour by $30 \mathrm{ppm}$ of Sevin. Therefore, it would seem logical that the respiration of soybean plants would also be affected. Another factor which could be studied would be the effects of Sevin on photosynthesis of soybean plants.

The autoradiographic analyses of $14 \mathrm{C}$-Sevin suggested that translocation is apoplastic with possible accumulation into the symplast. When the $14 \mathrm{c}$-Sevin was applied to the nutrient solution of the soybean plant, large amounts of the ${ }^{14} \mathrm{C}$-Sevin were translocated to most plant parts, while relatively little $14 \mathrm{C}$-Sevin had been translocated to the meristematic areas. Symplastic movement is doubtful since 
the ${ }^{14} \mathrm{C}$-Sevin applied to the treated leaves did not translocate from the food source to the actively metabolizing areas of the apices.

Lichtenstein et al. (1962) described the effects of insecticides on the anatomy of corn and pea roots. They noted that tracheary elements developed in a "unique wedgeshaped pattern" opposite the three protoxylem poles of pea roots. The terminology of "unique wedge-shaped pattern" could refer to the normal lateral root primordia which are a natural occurrence in soybean roots. The difference is that they occurred closer to the root apex than did those in the controls. This also applies to the differentiated cells of the protoxylem, protophloem, metaxylem and endodermis. The results suggest that because of an inhibition of development, these cells failed to elongate in advance of differentiation. This effect would indicate that an imbalance in plant growth hormones had been caused by Sevin or by its metabolites.

one possibility for the general decrease in plant growth could be the effect of Sevin on auxin formation. Auxin (Indol Acetic Acid) is produced in the apical meristem of the shoot and is transported toward the root apex (Galston and Davies, 1970). Auxin is a growth promoting material that influences the extension of cell walls and stimulates root initiation. If this balance is upset by the interference of Sevin, then a general decrease in growth would be apparent. This is just one possibility of 
what could affect the overall plant growth. It is not known just how insecticides affect other plant hormones (e.g., cytokinins, gibberellins, ethylene, etc.). This would be an interesting area for future research.

The root cap and epidermis had a small amount of purple pigment with increasing dosages of Sevin. The purple color was also noted on the silica sand. It could be a breakdown product of Sevin of 1-naphthol (C.Rice, pers. comm.) since the pure reagent turns purple when exposed to ultraviolet light.

A general vacuolization of cortical, stelar, epidermal and root cap tissues was noted at 21,25 and 55 ppm Sevin. Increased appearance of vacuolized cells close to the root apex could suggest that protein synthesis, essential to plant growth, was impaired. This could be the result of the effects of Sevin on cell division and consequently the normal development of root tissues. Analysis of cell length and width as well as the number of cells in the controls vs treated plants could more accurately determine if sevin did indeed impair cell division with subsequent effects on differentiation and maturation. Further development of this line of study could be an interesting area for future research.

The quiescent center did not seem to be affected at any concentration of Sevin in any of the soybean roots examined. Therefore it can be assumed, that when the 
deleterious enviroment of Sevin is removed, normal plant growth would resume.

Morphological and anatomical analyses revealed that few to no appreciable differences had occurred at 2, 9 and 19 ppm of Sevin, but at 21,25 and $55 \mathrm{ppm}$ of Sevin noticeable changes in root structure occurred.

Sevin is applied to the foliage of soybeans at concentrations ranging from 1.0 to 2.5 lbs Active Ingredient/ acre or 1.0 to 1.5 Actual Ingredient/ 100 gallons of water (Thompson, 1967). These concentrations range from 1 to 9 ppm in the field enviroment. Actual grower applications of Serin at 2 lbs Active Ingredient/ acre, applied to the second trifoliate leaf stage, have been observed to control a minor pest of soybeans (Vanessa cardui) but proved to be severely phytotoxic (I. Pedigo, University of Iowa, per. corm. .).

The concentrations used throughout the thesis are comparable to suggested field applications, but care must be taken to avoid suggesting similarities between foliar applications in the field and applications to the soil in a controlled enviromental situation. Factors such as microbial degradation, soil adsorption, ultraviolet degradation and other factors influencing sevin must be analyzed before any conclusions can be drawn.

Resistance to insecticides increases the dilemma as to what concentrations would be effective while not increasing the tolerance of the insect to the insecticide. Since 
soybean seedlings are injured by Sevin at 2 lbs Active Ingredient/ acre (approx. $9.0 \mathrm{ppm}$ ) the delicate balance between obtaining effective insect control and avoiding phytotoxic effects would be an invaluable area of future research.

Studies to date indicate that the beneficial aspects of Sevin exceed the negative aspects. Sevin does not remain in the biosphere and has a half-life of approximately 8 days in silica quartz sand (Table A-1). Therefore, any deleterious effects would be eliminated quickly. Although elimination of insecticides is impracticable at the present time, a more judicious use of insecticides such as in integrated pest control programs, would greatly benefit agriculture and the biosphere. 
SUMMARY

MORPHOLOGY

1) Complete expansion of the cotyledons treated with Sevin was retarded by 2 days in comparison with the controls. Increasing sevin concentrations produced progressively smaller cotyledons.

2) In all treated plants a pigment, presumably anthocyanin, that is normally present in untreated plants was absent from the hypocotyl and epicotyl.

3) Emergence of primary leaves was delayed with increasing concentrations of Sevin. At higher concentrations the trifoliate leaves never fully expanded even though primordia were present.

4) The roots were abnormally white and thin. As Sevin concentration increased, numerous lateral roots appeared close to the root apex. A purple color on the roots was noticed at 21,25 and 55 ppm of Sevin.

5) Root growth measurements showed that root tip growth of plants treated with 2, 9 and $19 \mathrm{ppm}$ of Sevin was not significantly different from that of the controls, but the difference among the 21, 25 and $55 \mathrm{ppm}$ treated plants and the controls was significant. The threshold concentration for the effects of Sevin on tip growth is between 19 and $21 \mathrm{ppm}$ of sevin. The threshold concentration for the emergence of lateral roots is between 21 and $25 \mathrm{ppm}$ of Sevin. 


\section{RADIOASSAY OBSERVATIONS}

1) When $14 \mathrm{C}$-Sevin was applied to the root $64 \%$ of the radioactivity was translocated into the primary and trifoliate leaves. The autoradiographs suggest that transport of ${ }^{14} \mathrm{C}$-Sevin is primarily apoplastic and possibly concentration of ${ }^{14} \mathrm{C}$-Sevin into the symplast occurs.

2) With foliar application to the primary and trifoliate leaves, 49 and $70 \%$ respectively, of the $14 \mathrm{C}-$ Sevin remained at the application site. As a result of infestations with aphids, some $14 \mathrm{C}$-Sevin may have been translocated to other plant parts.

ANATOMICAL ANALYSES

1) The quiescent center for all concentrations of Sevin showed little or no difference from the controls, but at doses of Sevin of $21 \mathrm{ppm}$ and above, the hemispherical outline of the quiescent center appeared less well defined than those at 2, 9 and $19 \mathrm{ppm}$ of Sevin.

2) At increased concentrations, noticeable hypoplasia of the root cap and epidermal tissues occurred. At 21,25 and $55 \mathrm{ppm}$ of sevin, the epidermis was a flattened, roughened area against the cortex.

3) At $21 \mathrm{ppm}$ of Sevin, the cortex was a shortened and flattened into compressed files of cells, and at $25 \mathrm{ppm}$, the cortex appeared to bulge at approximately 
300 um from the quiescent center. At $55 \mathrm{ppm}$, the cells of the cortex were difficult to distinguish from the vascular cylinder, and appeared more compressed and vacuolate than the controls. 4) Higher concentrations of Sevin affected the vascular cylinder by possibly inhibiting the rate of elongation, therefore, causing the appearance of maturing tracheary elements close to the quiescent center. Lateral root primordia were similarly affected at higher concentrations of Sevin.

5) The phloem, endodermis and parenchyma of the vascular cylinder showed no change in appearance in any of the treated plants. 


\section{LITERATURE C ITED}

Ball, H.J. 1956. Effect of insecticides on corn root growth. J. Econ. Entomo1. 49:230-233.

Caro, J.H., H.P. Freeman and B.C. Tumer. 1974. Persistence in soil-incorporated Carbaryl in a small watershed. J. Agr. Food Chem. 22:860-863.

Charnetski, W.A. 1973. Effects of Iindane on cell structure of pea pods. Can. J. Bot. 51:2111-2117.

Crafts, A.S. and S. Yamaguchi. 1964. The Autoradiography of Plant Materials. Univ. of California, Div. of Agricultural Sciences. 143 p.

Esau, K. 1953. Plant Anatamy. John Wiley \& Sons, Inc. Now York. $767 \mathrm{p}$.

Galston, A.W. and P.J. Davies. 1970. Control Mechanisms in Plant Development. Prentice Hall, New Jersey. 184 p.

Guseinov, M.K. 1970. Gig. Primen., Toksikol. Pestits. Klin. Otravlenii 8:174. (Refer to Caro, J.H., 1974)

Howell, R.W. 1975. Golden beans from China now our no. 1 cash crop. Yearbook of Agriculture 1975:225-236.

Ivanova, I.N. and Y.G. Molozhanova. 1973. Gig. Sanit. 38:24. (Refer to Caro, J.H., 1974)

Johnson, D.P., F.E. Critchfield and B.W. Arthur. 1963. Colorimetric determination of 1-naphthyl $\mathrm{N}$-methylcarbamate in agricultural crops. J. Arg. Food. Chem. $11: 77$.

Johnson, D.P. and H.A. Stansbury. 1965. Adaptation of Sevin insecticides (Carbaryl) residue method to various crops. J. Agr. Food Chem. 13:235-238.

Kazano, H., P.C. Kearney and D.D. Kaufman. 1972. Metabolism of methylcarbamate insecticides in soils. J. Agr. Food Chem. 20:975-978.

Kostoff, D. 1948. Atypical growth, abnormal mitosis, polyploidy and chramosome fragmentation induced by hexaohlorocyclohexane. Nature 162:845-846.

Kuhr, R.J. 1970. Metabolism of carbamate insecticide chemicals in plants and insects. J. Agr. Food Chem. 18:1023-1030. 
Lichtenstein, E.P., W.F. Millington and G.T. Cowley. 1962. Effects of various insecticides on growth and respiration of plants. J. Agr. Food Chem. 10:251-256.

Miksche, J.P. 1961. Developmental morphology of Glycine max (I.) Merr. Agr. J. 53:121-128.

Mitchell, R.I. and W.J. Russell. 1971. Root development and rooting patterns of soybeans (Glycine max (L.) Merrili) evaluated under field conditions. Agr. J. 63:313-316.

National Academy of Science. 1975. The report of the corn/ soybean study team. Studies in problems of pest control. Enviromental Studies Board, National Research Council. Washington, D.C. $169 \mathrm{p}$.

Nybom, N. and B. Knutsson. 1947. Investigations on $\mathrm{G}-$ mitosis in Allium cepa. I. The cytological effect of hexachlorohexane. Hereditas 33:220-234.

Sass, J.E. 1958. Botanical Histotechnique. Iowa State Colloge Press, Iowa. $152 \mathrm{p}$.

Scholes, M.E. 1953. The effect of hexachlorocyclohexane in roots of the onion (Allium cepa) and strawberry (Frageria vesca). J. Hort. Sci. 28:49-67.

Simkover, H.G. and R.D. Shenefelt. 1952. Phytotoxicity of same insecticides to coniferous seedlings with particular reference to benzene hexachloride. J. Econ. Entomol. 45:11-15.

Steel, R.G. and J.H. Torrie. 190. Principles and procedures of statistics. McGraw-Hill Book Co., Inc. New York. $481 \mathrm{p}$.

Sun. C.N. 1955. Growth and development of primary tissues in aerated and non-aerated roots of soybeans. Bull. Torrey Bot. Club 82:49-52.

1957. Zonation and organization of root apical merlstem of Glycine max. Bull. Torrey Bot. Club 84: 69-78.

Thompson, W.T. 1967. Agricultural chemicals book. I. Insecticides, acaracides and ovierds. Thompson Publications, California $366 \mathrm{p}$.

von Rumiker. V.W., E.W. Lawless and A.F. Meiners. 1974. Production, distribution, use and enviromental impact potential of selected pesticides. EPA 540/174-001. $439 \mathrm{p}$. 
Weaver, H.I. 1960. Vascularization of the root-hypocotyl-cotyledon axis of Glycine max (I.) Merrill. Phytomorphology 10:82-86. 
64.

APPENDIX 
65.

Fig. A-1. Standard curve of the amount of Sevin ( $\mu \mathrm{g} / \mathrm{ml})$ to Optical Density. 
66.

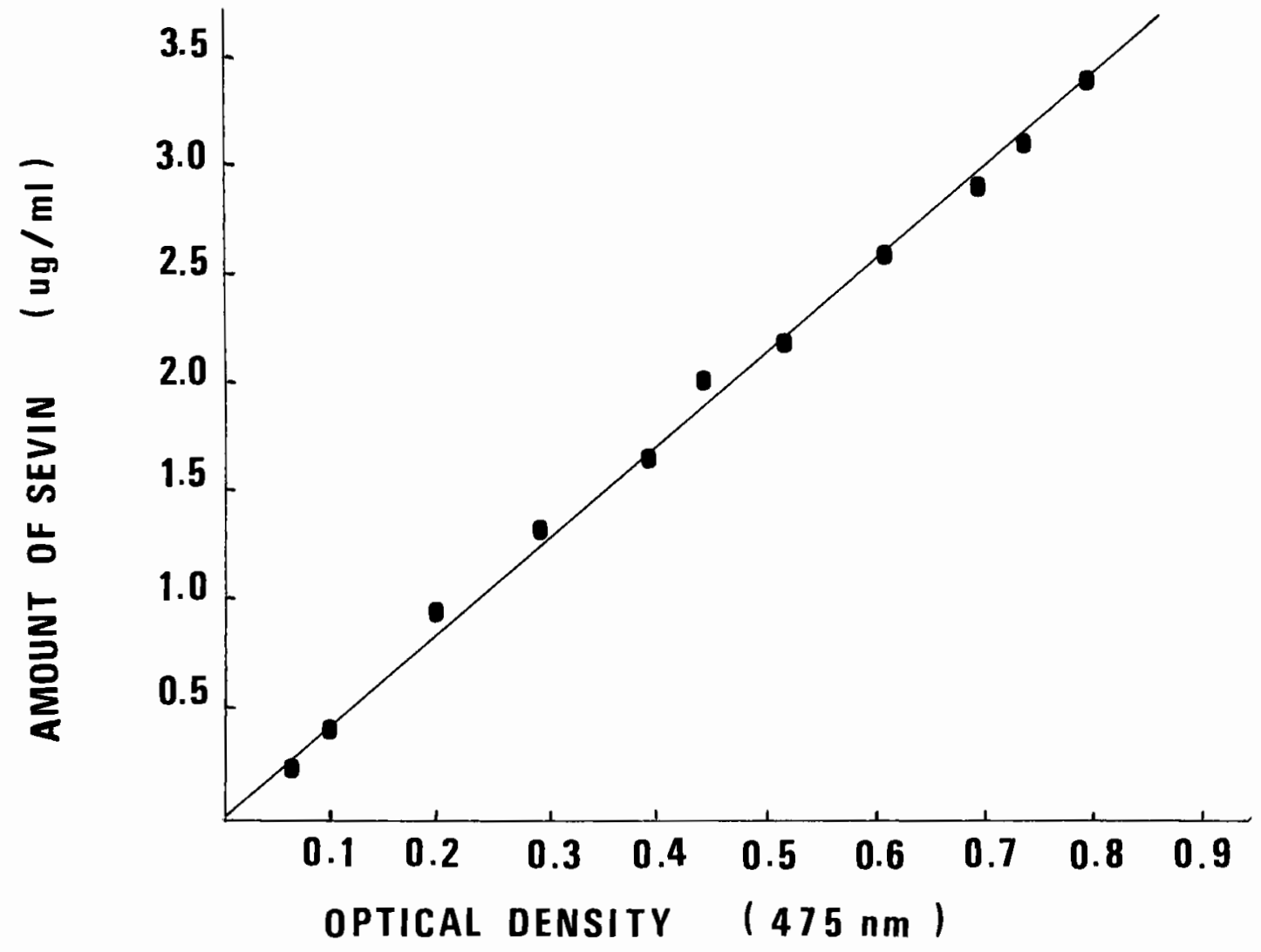


Table A-1. The mean concentration of Sevin at the onset (Day 0) and termination (Day 10) of each experiment.*

Sevin Concentration, ppm

Initial

(Day 0)

Final

(Day 10)

\begin{tabular}{ll}
2 & 1 \\
9 & 2 \\
19 & 9 \\
21 & 5 \\
25 & 13 \\
55 & 19 \\
\hline
\end{tabular}

* Each experiment consisted of 3 replicates. 